\title{
Molecular insights into the microbial formation of marine dissolved organic matter: recalcitrant or labile?
}

\author{
B. P. Koch ${ }^{1,2}$, G. Kattner ${ }^{1}$, M. Witt ${ }^{3}$, and U. Passow ${ }^{4}$ \\ ${ }^{1}$ Alfred-Wegener-Institut Helmholtz-Zentrum für Polar- und Meeresforschung, Am Handelshafen 12, \\ 27570 Bremerhaven, Germany \\ ${ }^{2}$ University of Applied Sciences, An der Karlstadt 8, 27568 Bremerhaven, Germany \\ ${ }^{3}$ Bruker Daltonik GmbH, Fahrenheitstraße 4, 28359 Bremen, Germany \\ ${ }^{4}$ Marine Science Institute, UC Santa Barbara, Santa Barbara, CA 93106-6150, USA \\ Correspondence to: B. P. Koch (boris.koch@awi.de)
}

Received: 14 February 2014 - Published in Biogeosciences Discuss.: 25 February 2014

Revised: 4 June 2014 - Accepted: 2 July 2014 - Published: 11 August 2014

\begin{abstract}
The degradation of marine dissolved organic matter (DOM) is an important control variable in the global carbon cycle. For our understanding of the kinetics of organic matter cycling in the ocean, it is crucial to achieve a mechanistic and molecular understanding of its transformation processes. A long-term microbial experiment was performed to follow the production of non-labile DOM by marine bacteria. Two different glucose concentrations and dissolved algal exudates were used as substrates. We monitored the bacterial abundance, concentrations of dissolved and particulate organic carbon (DOC, POC), nutrients, amino acids and transparent exopolymer particles (TEP) for 2 years. The molecular characterization of extracted DOM was performed by ultrahigh resolution Fourier transform ion cyclotron resonance mass spectrometry (FT-ICR MS) after 70 days and after $\sim 2$ years of incubation. Although glucose quickly degraded, a non-labile DOC background (5-9\% of the initial DOC) was generated in the glucose incubations. Only $20 \%$ of the organic carbon from the algal exudate degraded within the 2 years of incubation. The degradation rates for the nonlabile DOC background in the different treatments varied between 1 and $11 \mu$ mol DOC L ${ }^{-1}$ year $^{-1}$. Transparent exopolymer particles, which are released by microorganisms, were produced during glucose degradation but decreased back to half of the maximum concentration within less than 3 weeks (degradation rate: $25 \mu \mathrm{g}$ xanthan gum equivalents $\mathrm{L}^{-1} \mathrm{~d}^{-1}$ ) and were below detection in all treatments after 2 years. Additional glucose was added after 2 years to test whether labile substrate can promote the degradation of background
\end{abstract}

DOC (co-metabolism; priming effect). A priming effect was not observed but the glucose addition led to a slight increase of background DOC. The molecular analysis demonstrated that DOM generated during glucose degradation differed appreciably from DOM transformed during the degradation of the algal exudates. Our results led to several conclusions: (i) based on our experimental setup, higher substrate concentration resulted in a higher concentration of nonlabile DOC; (ii) TEP, generated by bacteria, degrade rapidly, thus limiting their potential contribution to carbon sequestration; (iii) the molecular signatures of DOM derived from algal exudates and glucose after 70 days of incubation differed strongly from refractory DOM. After 2 years, however, the molecular patterns of DOM in glucose incubations were more similar to deep ocean DOM whereas the degraded exudate was still different.

\section{Introduction}

Refractory dissolved organic matter (DOM) in the oceans represents a large reservoir of organic carbon in the global carbon cycle (642 Pg C, Hansell, 2013). The ultimate sources of marine DOM are primary production in the sunlit surface layer of the ocean and continental runoff. If this DOM resists degradation long enough (weeks to months) to be removed from the surface ocean by physical processes, its transport to depths can be an important sink for atmospheric carbon (Carlson et al., 1994, 2010). The formation of refractory 
DOM is a prerequisite for an efficient sequestration of dissolved organic carbon (DOC; $86 \mathrm{Tg} \mathrm{C}_{\mathrm{Cear}}{ }^{-1}$; Hansell et al., 2009) as it occurs in areas of deep-water formation, particularly in the polar oceans.

The average DOC atom in the ocean has a radiocarbon age of 4000-6000 years (Bauer et al., 1992). However, for specific DOM fractions and molecular formulas, the residence time can be substantially longer (Loh et al., 2004; Lechtenfeld et al., 2014). It is not clear how this carbon buffer will evolve in the future global biogeochemical cycle and how it affects the climate system (Denman et al., 2007). The efficacy of forming refractory organic matter from labile substrates, which depends on the environmental conditions, is critical for the magnitude of the sequestration flux.

Microbial utilization and modification is probably the most important process for the formation of refractory DOM (Jiao et al., 2010 and references therein). It increases the average marine DOC turnover time and efficiently contributes to carbon sequestration. In experimental incubations, marine bacteria form non-labile organic matter from simple substrates such as glucose. These non-labile substances persist for up to more than a year (e.g. Skoog et al., 1999; Ogawa, 2001; Gruber et al., 2006), suggesting that microbial activity may indeed be responsible for converting labile photosynthates into refractory organic matter. It is unknown, however, whether the organic material produced in such experiments is chemically similar to refractory DOM and therefore could be preserved on timescales beyond those achievable in lab incubations.

The persistence of refractory DOC in the ocean is attributed to its intrinsic chemical stability (e.g. Koch et al., 2005; Hertkorn et al., 2006) and its low concentration, especially in the deep ocean (Kattner et al., 2011). The ability or inability of the in situ microbial community to express membrane transporters for DOM uptake may also control DOM degradation (e.g. Arnosti, 2004). The lack of essential inorganic nutrients and trace elements and labile (bioavailable) organic substrates (called co-metabolism or priming effect) can also impede microbial degradation of organic matter (e.g. Horvath, 1972; Alderkamp et al., 2007; Bianchi, 2011). Presumably, a combination of all of these factors leads to the long average turnover time of marine DOM.

Many marine microorganisms release ubiquitous amounts of exopolymeric substances (Myklestad, 1995). A surfaceactive fraction of marine exopolymers, which are rich in acidic polysaccharides, abiotically forms a class of particles called transparent exopolymer particles (TEP; Mopper et al., 1995; Zhou et al., 1998; Passow, 2000). Exudates from phytoplankton and bacteria are often rich in TEP and their dissolved precursors (Myklestad, 1995; Passow, 2002b; OrtegaRetuerta et al., 2009), which exist in a size continuum from fibrillar macromolecules (Leppard, 1995) to TEP 100s of micrometers long (Verdugo et al., 2004). Micro- and nano-gels are thought to be identical to TEP precursors, although this is still open to discussion (Verdugo and Santschi, 2010). As particulates, TEP play an essential role for the aggregation and vertical flux of particulate organic matter (POM) (Alldredge et al., 1993; Passow et al., 1994; Logan et al., 1995). It has even been suggested that TEP concentration determines aggregation (Passow et al., 1994; Arrigo, 2007; Gardes et al., 2011). TEP also provide surfaces and substrates for bacteria and archaea, creating hot spots of microbial activity (Smith et al., 1992; Passow and Alldredge, 1994; Azam and Long, 2001). Despite their dominant role in marine carbon cycling, very little is known about the lability of TEP, especially on timescales longer than 1 or 2 weeks (Passow, 2002a).

In the past, in vitro degradation experiments mainly provided bulk chemical characteristics and molecular information for a small fraction of refractory DOM (e.g. Lara and Thomas, 1995; Ogawa et al., 2001). The application of ultrahigh resolution Fourier transform ion cyclotron resonance mass spectrometry (FT-ICR MS) resulted in major advances in the molecular characterization of complex organic matter samples (e.g. Kujawinski et al., 2002; Stenson et al., 2002). The technique is suitable for identifying molecular formula fingerprints of different sources (e.g. Hughey et al., 2007; Gonsior et al., 2011; Schmidt et al., 2011) and transformation processes (Rodgers et al., 2000; Kujawinski et al., 2004) of organic matter. Based on FT-ICR MS analyses, it has been previously hypothesized that the molecular composition of all refractory organic matter is similar and independent of its ultimate source (Koch et al., 2005; Rossel et al., 2013). Conceptually, this contradicts the findings that sources and transformation processes are molecularly imprinted in organic matter. A better mechanistic understanding of the processes which convert labile material (which contains the original biochemical signal) into refractory organic matter (which represents the sequestration potential) is required to resolve this contradiction. So far, such kinetics are not well constrained although crucial for the conservation of molecular biomarker signals.

In our experiments, we investigated changes in DOM and TEP concentrations and shifts in the molecular composition of DOM during the microbial utilization of glucose and an algae exudate during a period of 2 years. The main goal of the study was to test the hypothesis that the degradation of different substrates leads to refractory DOM with similar molecular characteristics. Specifically, we tested if DOM with refractory molecular characteristics can be generated on timescales of less than 3 months. Since the relative contribution of nitrogen (and sulfur) heteroatoms in organic matter can determine bioavailability, we investigated their incorporation into persistent DOM. We also examined if the addition of labile substrates results in an increased mineralization of refractory DOM (co-metabolism; priming effect) and verified the hypothesis that the majority of TEP are labile and removed within weeks. 
Table 1. Experimental setup: three different substrates were incubated in $50 \mathrm{~L}$ glass bottles for 70, 695 and 734 days.

\begin{tabular}{|c|c|c|c|c|c|c|c|}
\hline Bottle & $\begin{array}{l}\text { Medium } \\
(45 \mathrm{~L})\end{array}$ & $\begin{array}{l}\text { Inoculum } \\
\quad(1 \mathrm{~L})\end{array}$ & $\begin{array}{c}\text { Glucose } \\
(320 \mu \mathrm{MC})\end{array}$ & $\begin{array}{l}\text { Algal exudate } \\
(140 \mu \mathrm{MC})\end{array}$ & $\begin{array}{c}{ }^{13} \mathrm{C} \text { glucose } \\
(45 \mu \mathrm{MC})\end{array}$ & $\begin{array}{l}\text { DOM extraction } \\
\text { after (days) }\end{array}$ & Treatment/control \\
\hline${ }^{\mathrm{sc}}$ [none] & $x$ & $<0.2 \mu \mathrm{m}$ & - & - & - & 70 & Sterile background control \\
\hline${ }^{\mathrm{sc}}[\mathrm{Glc}]$ & $x$ & $<0.2 \mu \mathrm{m}$ & $x$ & - & - & 70 & Sterile glucose control \\
\hline $\mathrm{sc}_{\text {[exud] }}$ & $x$ & $<0.2 \mu \mathrm{m}$ & - & $x$ & - & 70 & Sterile exudate control \\
\hline${ }^{c}$ [none] & $x$ & $<3 \mu \mathrm{m}$ & - & - & - & 70 & Background control \\
\hline [Glc] & $x$ & $<3 \mu \mathrm{m}$ & $x$ & - & - & 70 & {$[\mathrm{Glc}]$} \\
\hline [exud] & $x$ & $<3 \mu \mathrm{m}$ & - & $x$ & - & 70 & [exud] \\
\hline$\left[{ }^{13} \mathrm{Glc}\right]$ & $x$ & $<3 \mu \mathrm{m}$ & - & - & $x$ & 70 & {$\left[{ }^{13} \mathrm{Glc}\right]$} \\
\hline [Glc] & $x$ & $<3 \mu \mathrm{m}$ & $x$ & - & - & 695 & {$[\mathrm{Glc}]$} \\
\hline [Glc] & $x$ & $<3 \mu \mathrm{m}$ & $x$ & - & - & 695 & [Glc]; co-metabolism \\
\hline [exud] & $x$ & $<3 \mu \mathrm{m}$ & - & $x$ & - & 695 & [exud]; co-metabolism \\
\hline$\left[{ }^{13} \mathrm{Glc}\right]$ & $x$ & $<3 \mu \mathrm{m}$ & - & - & $x$ & 695 & {$\left[{ }^{13} \mathrm{Glc}\right]$} \\
\hline
\end{tabular}

\section{Material and methods}

\subsection{Experimental setup}

Eleven $50 \mathrm{~L}$ glass bottles containing seven treatments and four controls were incubated for 70,695 as well as 734 days (second addition of glucose after 699 days) in the dark at $0{ }^{\circ} \mathrm{C}$ (Table 1). The general design of the experiment followed that of Ogawa et al. (2001). Briefly, substrate and bacterial inoculum were added to sterile artificial seawater and changes in DOM were monitored.

The incubation bottles (Table 1) consisted of (i) three replicate treatments that contained glucose ([Glc]), (ii) two that contained dissolved algae exudates ([exud]) and (iii) two that contained ${ }^{13} \mathrm{C}$-labeled glucose $\left(\left[{ }^{13} \mathrm{Glc}\right]\right.$; D-glucose-1${ }^{13} \mathrm{C}$, Sigma). These treatments were inoculated with bacteria. Additionally, four different controls were prepared: the two background controls received inoculum or sterilefiltered inoculum, respectively, but no substrate $\left({ }^{\mathrm{C}}[\right.$ none]) and ( ${ }^{\text {sc }}$ [none]). The two other sterile controls received sterilefiltered inoculum and either exudates ( ${ }^{\mathrm{sc}}[$ exud]) or glucose ( $\left.{ }^{\text {sc }}[\mathrm{Glc}]\right)$. A natural microbial community collected from Antarctic surface water was used as the bacterial inoculum. After 699 days of incubation, glucose was added to one [exud] and one [Glc] treatment to evaluate the potential influence of co-metabolism on DOC degradation (Table 1). Samples for bulk parameters were collected at 11 to 15 time steps during the incubations and samples for the DOM extraction and molecular formula characterization by ultrahigh resolution mass spectrometry were collected after 70 and 695 days.

Results are primarily presented as averages of replicates with identical substrates ( $n=3$ for glucose, $n=2$ for exudates, $n=2$ for ${ }^{13} \mathrm{C}$-labeled glucose). In the following, the treatments are labeled with the type of substrate in square brackets $\left([\mathrm{Glc}]_{x} \text {; [exud }\right]_{x}$; or $\left.\left[{ }^{13} \mathrm{Glc}\right]_{x}\right)$. The subscript index $(x)$ indicates the day or period of sampling if applicable.

\subsection{Preparation of experiment}

The $50 \mathrm{~L}$ glass bottles were acid $(\mathrm{HCl}, 2 \mathrm{M}$, Merck, pro analysi) and base washed $(\mathrm{NaOH}, 2 \mathrm{M}$, Merck, pro analysi) and then rinsed with ultrapure water (Millipore). Each bottle was filled with $\sim 45 \mathrm{~L}$ of sterile-filtered $(0.2 \mu \mathrm{m}$, Polycap, Whatman) artificial seawater, containing $\mathrm{NaCl}\left(24.99 \mathrm{~g} \mathrm{~L}^{-1}\right), \mathrm{MgCl}_{2} \times 6 \mathrm{H}_{2} \mathrm{O}\left(11.13 \mathrm{~g} \mathrm{~L}^{-1}\right), \mathrm{Na}_{2} \mathrm{SO}_{4}$ (4.16 g L $\left.{ }^{-1}\right), \mathrm{CaCl}_{2} \times 2 \mathrm{H}_{2} \mathrm{O}\left(1.58 \mathrm{~g} \mathrm{~L}^{-1}\right), \mathrm{KCl}\left(0.79 \mathrm{~g} \mathrm{~L}^{-1}\right)$ and $\mathrm{NaHCO}_{3}\left(0.17 \mathrm{~g} \mathrm{~L}^{-1}\right)$ dissolved in ultrapure water. All salts except $\mathrm{CaCl}_{2}$ (sterile filtered) were pre-combusted $\left(500^{\circ} \mathrm{C}, 5 \mathrm{~h}\right)$ before use. Sterile-filtered nutrient solutions were added as $\mathrm{NaNO}_{3}, \mathrm{NH}_{4} \mathrm{Cl}$ and $\mathrm{KH}_{2} \mathrm{PO}_{4}$, each at a final concentration of $\sim 52 \mu \mathrm{mol} \mathrm{L}^{-1}$.

Sterile-filtered $(0.2 \mu \mathrm{m}$, precleaned, Minisart 16534, Sartorius) solutions were added as substrates: (i) glucose (final concentration: $\sim 320 \mu \mathrm{mol} \mathrm{CL^{-1 }}$ ), (ii) algae-DOM-derived from a culture of the haptophyte Isochrysis galbana (final concentration: $\sim 140 \mu \mathrm{mol} \mathrm{DOC} \mathrm{L}^{-1}$ ) and (iii) ${ }^{13} \mathrm{C}$-labeled

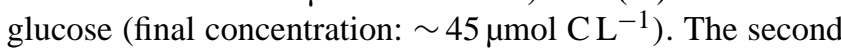
addition of glucose (at day 699) was to a final concentration of $\sim 170 \mu \mathrm{mol} \mathrm{CL^{-1 }}$. Isochrysis galbana was grown axenically in a commercial facility in $\mathrm{f} / 2$ medium (Guillard and Ryther, 1962; Guillard, 1975; https://ncma.bigelow.org/ node/79) to high density and cells were removed by sequential filtration (Sartobran 300: $0.45 \mu \mathrm{m}$ followed by Minisart, Sartorius: $0.2 \mu \mathrm{m}$ ). It would have been unfeasible to generate $>10 \mathrm{~L}$ of exudates from an axenic Antarctic diatom under standard laboratory conditions. After filtration, the exudates were stored at $0^{\circ} \mathrm{C}$ in the dark until the experiment started. Finally, $3 \mathrm{~L}$ of this filtrate were added to the respective treatments (Table 1).

All samples, except the two control samples ${ }^{\mathrm{c}}[\mathrm{Glc}]$ and ${ }^{\mathrm{c}}$ [exud] were incubated with $1 \mathrm{~L}$ inoculum $(3 \mu \mathrm{m}$ filtrate, PC, Nuclepore), collected in the Weddell Sea (Antarctica) at a water depth of $100 \mathrm{~m}$ (12 December 2004; 67 $49^{\prime} \mathrm{S}$, $55^{\circ} 33^{\prime} \mathrm{W}$; R/V Polarstern, PS67/006-118) and stored in the 


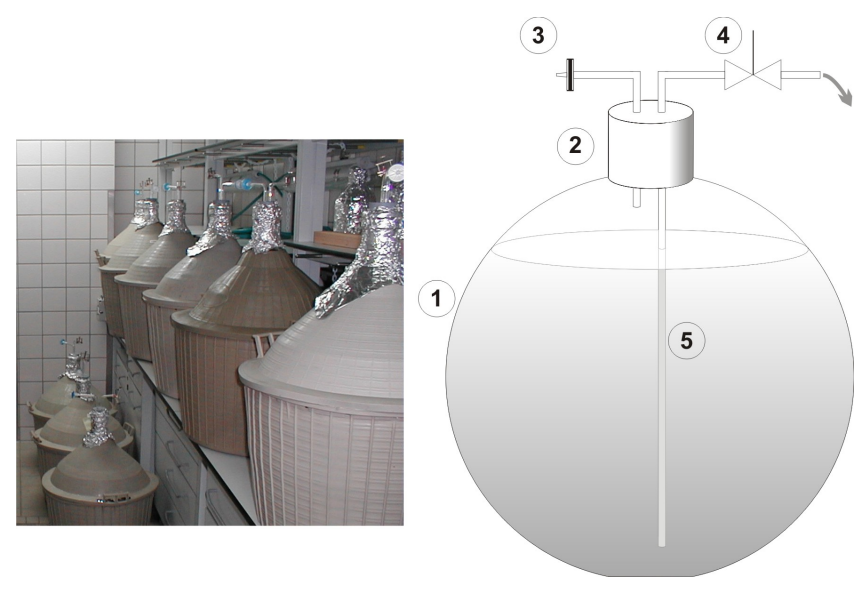

Figure 1. Experimental setup: 11 glass bottles (1, total volume 49 L) each of which contained sterile artificial seawater medium (including additional nutrients), $1 \mathrm{~L}$ seawater inoculum and three different substrates. The bottles were closed with a rubber lid (2) and air exchange was enabled by a sterile $0.2 \mu \mathrm{m}$ filter (3). Samples were taken through a valve (4) using a peristaltic pump and glass (5) and Teflon tubing.

dark at $0{ }^{\circ} \mathrm{C}$ until the beginning of the experiment 5 months later. Inoculum used for the sterile controls ${ }^{\mathrm{sc}}$ [none], ${ }^{\mathrm{sc}}[\mathrm{Glc}]$ and ${ }^{\mathrm{sc}}$ [exud] was sterile filtered using Teflon filters $(0.2 \mu \mathrm{m}$, Polycap, Whatman). All bottles were topped off to a total volume of $49 \mathrm{~L}$ with sterile-filtered artificial seawater and sealed with a rubber plug (Fig. 1). All bottles were dark-incubated at $0^{\circ} \mathrm{C}$ in a cold room.

\subsection{Sampling}

During the first phase of the experiment each bottle was subsampled for bacteria, TEP, DOC, particulate organic carbon (POC), glucose and amino acid determination at eleven time points (days 2, 4, 6, 9, 13, 16, 21, 27, 34, 41, 55). Prior to sampling, each bottle was mixed for $2 \mathrm{~min}$ to ensure sample homogenization. Sampling was performed using a glass tube which was installed through the cork of the bottle and sealed with a valve (Fig. 1). The water was sucked up using a peristaltic pump and Teflon tubing. The first $\sim 100 \mathrm{~mL}$ of sample was discarded. Sterile air exchange in the headspace of each bottle was enabled by a filter $(0.2 \mu \mathrm{m}$, Minisart 16534 , Sartorius) which was also inserted into the cork.

After 70 days, the first phase of the experiment was terminated (Table 1). The remaining volume of all controls and one treatment of each type, i.e. [exud], [Glc] and $\left[{ }^{13} \mathrm{Glc}\right]$, was filtered $(0.2 \mu \mathrm{m}$, Polycap, Whatman $)$ and solid-phase extracted (PPL, Varian). The four remaining bottles were incubated another 625 days (subsampling at 303/323 days). One [Glc] and the second $\left[{ }^{13} \mathrm{Glc}\right]$ treatment as well as half of the third [Glc] and the second [exud] sample volumes were sampled at day 695 ending phase 2 . The remaining treatments
[Glc] and [exud] received a second addition of glucose on day 699 and were incubated for another 35 days (phase 3).

At every sampling day, unfiltered and filtered $(0.2 \mu \mathrm{m}$; precleaned, Minisart 16534, Sartorius) samples ( $15 \mathrm{~mL}$ each) were collected for instantaneous organic carbon analyses. Three additional unfiltered samples $(15 \mathrm{~mL}$ each) were filled into pre-combusted $\left(500^{\circ} \mathrm{C}, 5 \mathrm{~h}\right)$ glass ampoules (Wheaton) and frozen for later analysis of total organic carbon (TOC) and total dissolved nitrogen (TDN). Filtered samples for amino acid analyses $(0.2 \mu \mathrm{m}, 10 \mathrm{~mL})$ were filled into precombusted ampoules, $10 \mathrm{M}$ HCL $(1: 1, v: v$, Suprapur, Merck) was directly added and samples were stored frozen $\left(-28^{\circ} \mathrm{C}\right)$ in the dark. $40 \mathrm{~mL}$ of samples were filtered $(0.45 \mu \mathrm{m}, \mathrm{GMF}$, Whatman), filled into polyethylene (PE) bottles and stored frozen $\left(-28^{\circ} \mathrm{C}\right)$ for later nutrient measurements. Approximately $1 \mathrm{~L}$ of sample water was filled into PE bottles, filtered (0.4 $\mu \mathrm{m}$ PC; Poretics) and stained immediately for TEP analysis. For bacterial counts, $60 \mathrm{~mL}$ of sample was filled into PE bottles and fixed with formaldehyde (10\% final concentration); replicate filters were prepared and counted within 1-4 weeks.

\subsection{DOM extraction}

Samples for DOM extraction were collected after 70 and 695 days (Table 1$)$ by sequential filtration $(1 \mu \mathrm{m}, 0.2 \mu \mathrm{m}$, Whatman Polycap 75 TF) of 16-34 L, followed by acidification to $\mathrm{pH} 2-3$ using $\mathrm{HCl}$ (Merck, Suprapur) and extraction (Dittmar et al., 2008) using pre-cleaned solid-phase extraction (SPE) cartridges (PPL, BondElut, $5 \mathrm{~g}$ ). The extraction was performed by gravity at a speed of $<12 \mathrm{~mL} \mathrm{~min}^{-1}$. The cartridges were eluted with 20 or $40 \mathrm{~mL} \mathrm{MeOH}$ (Merck, LiChrossolv), depending on sample volume, equivalent to an average enrichment factor of 750. Extracts were frozen $\left(-28^{\circ} \mathrm{C}\right)$ in pre-combusted $\left(500^{\circ} \mathrm{C}, 5 \mathrm{~h}\right)$ glass ampoules.

\subsection{Bacterial and flagellate abundance}

Bacteria were filtered onto two replicate black filters $(0.2 \mu \mathrm{m}$ Polycarbonate, Poretics), stained with 4',6diamidino-2-phenylindole (DAPI) or $\mathrm{N}^{\prime}, \mathrm{N}^{\prime}$-dimethyl- $\mathrm{N}$ [4-[(E)-(3-methyl-1,3-benzothiazol-2-ylidene)methyl]-1phenylquinoline-1-ium-2-yl]-N-propylpropane-1,3-diamine (SYBR Green), stored frozen and counted within 1-4 weeks using a Zeiss fluorescence microscope (for details see Porter and Feig, 1980; Noble and Fuhrman, 1998). At least 300 bacteria per replicate filter were counted in at least 10-20 fields of vision. Bacteria were enumerated in two size classes $(<2 \mu \mathrm{m}$ and $>2 \mu \mathrm{m})$ in samples from day 34 and 323 .

The presence of flagellates was investigated on day 28 in two sub-samples ([exud] and [Glc]). Samples $(60 \mathrm{~mL})$ were filtered onto black filters $(0.8 \mu \mathrm{m}$ Polycarbonate, Poretics), stained immediately with DAPI and counted via fluorescence microscopy (Kemp et al., 1993). Both test samples were 
negative, suggesting that protozoa did not play a prominent role in bacterial dynamics.

\subsection{Transparent exopolymer particles}

TEP were filtered directly after sampling $(15-250 \mathrm{~mL}$ filter ${ }^{-1}$ ) in quadruplicates onto $0.4 \mu \mathrm{m}$ filters (Polycarbonate, Poretics), stained with Alcian Blue and stored frozen until colorimetrical analysis 1-10 days later. The Alcian Blue staining capacity was calibrated with xanthan gum and quantified based on the absorptivity at $787 \mathrm{~nm}$. Concentrations are given in $\mu \mathrm{g}$ xanthan equivalents per liter (Passow and Alldredge, 1995).

\subsection{Dissolved and particulate organic carbon and nitrogen}

DOC, total dissolved nitrogen (TDN) and total organic carbon (TOC, unfiltered sample) were determined by high temperature catalytic oxidation and subsequent non-dispersive infrared spectroscopy and chemiluminescence detection (TOC-VCPN, Shimadzu). Final TOC, DOC and TDN concentrations are average values of triplicate measurements. If the standard variation or the coefficient of variation exceeded $0.1 \mu \mathrm{M}$ or $1 \%$, respectively, up to two additional analyses were performed and outliers were eliminated. After each batch of five samples, one reference standard (DOC-DSR, Hansell Research Lab, University of Miami, USA), one ultrapure water blank and one potassium hydrogen phthalate standard were measured. The limit of detection $(3 \sigma$ of the blank) and quantitation ( $9 \sigma$ of the blank) was 7 and $21 \mu \mathrm{mol}$ $\mathrm{CL}^{-1}$, respectively. The accuracy was $\pm 5 \%$. POC was determined by the difference between TOC and DOC measurements.

\subsection{Inorganic nutrients, free glucose and total hydrolysable amino acids}

Nutrients were measured using an autoanalyzer (Evolution III, Alliance Instruments) according to seawater standard methods (Kattner and Becker, 1991; Grasshoff et al., 1999). Free glucose was analyzed using high pressure anion exchange chromatography with pulsed amperometric detection based on previous methods (Johnson and LaCourse, 1990; Mopper et al., 1992; Engbrodt and Kattner, 2005). Samples were injected using an autosampler (AS-4000, MerckHitachi) and an ion chromatography system (DX-500; PA1 guard column, $4 \times 250 \mathrm{~mm}$ anion-exchange PA- 1 column, ED-40 electrochemical detector, all Dionex). The detection limit was $20 \mathrm{nM} \mathrm{C}$. Total hydrolysable amino acids were determined on days 4, 16 and 41, based on the method by Fitznar et al. (1999).

\subsection{Ultrahigh resolution mass spectrometry (FT-ICR MS)}

FT-ICR MS analyses were carried out as described previously (e.g. Lechtenfeld et al., 2013). In summary, prior to analysis, DOM extracts were diluted with methanol: water $(1: 1, v: v)$. Samples were ionized by electrospray ionization (ESI, Apollo II electrospray ionization source, Bruker Daltonik, Bremen, Germany) in negative mode at an infusion flow rate of $120 \mu \mathrm{Lh}^{-1}$ on a Fourier transform ion cyclotron resonance mass spectrometer (FT-ICR MS; SolariX, Bruker Daltonik, Bremen, Germany) equipped with a $12 \mathrm{~T}$ refrigerated, actively shielded, superconducting magnet (Bruker Biospin, Wissembourg, France). 300 scans were added to one mass spectrum. The magnitude threshold for the peak detection was set to a signal-to-noise ratio of $\geq 4$. Mass spectra were recalibrated internally with compounds, which were repeatedly identified in marine DOM samples (Koch et al., 2008; Flerus et al., 2011; $m / z: 247.06120,297.13436$, 327.14493, 369.15549, 397.15041, 439.16097, 483.18719, $551.24979,595.23962)$. The average mass accuracy of the internal calibrants was below $100 \mathrm{ppb}$.

\subsection{FT-ICR MS data evaluation}

All ions were singly charged as confirmed by the spacing of the related ${ }^{12} \mathrm{C}_{n}$ and ${ }^{13} \mathrm{C}^{12} \mathrm{C}_{n-1}$ mass peaks. The spectra were evaluated in the mass range of $200-600 \mathrm{~m} / z$. The base peak in this mass range was defined as $100 \%$ and relative intensities for all other peaks were calculated accordingly. For the process of formula assignment, only peaks with a relative intensity between $2-100 \%$ were considered. Molecular formulas were calculated from $m / z$ values allowing for elemental combinations ${ }^{12} \mathrm{C}_{0-\infty}{ }^{13} \mathrm{C}_{0-1}$ ${ }^{1} \mathrm{H}_{0-\infty}{ }^{14} \mathrm{~N}_{0-4}{ }^{16} \mathrm{O}_{0-\infty}{ }^{32} \mathrm{~S}_{0-2}{ }^{34} \mathrm{~S}_{0-1}$ and a mass accuracy threshold of $|\Delta m| \leq 0.5 \mathrm{ppm}$. The double bond equivalent $(\mathrm{DBE}=1+1 / 2(2 \mathrm{C}-\mathrm{H}+\mathrm{N}))$ of a valid neutral formula had to be an integer value $\geq 0$ and the "nitrogen rule" was applied (Koch et al., 2007). Formulas which were detected in a process blank (PPL extraction of ultrapure water) and in the list of potential surfactants (Lechtenfeld et al., 2013) were removed from the entire data set. Formulas containing a ${ }^{13} \mathrm{C}$ or ${ }^{34} \mathrm{~S}$ isotope and did not correspond to a parent formula $\left({ }^{12} \mathrm{C}\right.$, ${ }^{32} \mathrm{~S}$ ) were also removed from the data set.

As an additional level of formula validation, all formulas were sorted according to DBE and ppm (Fig. 2a, b). A small proportion of formulas corresponded to very high DBE values, many of which were false assignments of sulfur containing compounds (as identified by the peak ratio of the parent and daughter ions). We therefore used $\mathrm{DBE}<20$ as an additional cut-off which resulted in an unambiguous assignment for the complete data set. The distribution of mass accuracy also showed that the majority of the assigned formulas are well within the $0.5 \mathrm{ppm}$ threshold. After these validation steps, we excluded the stable isotopes ${ }^{13} \mathrm{C}$ and 

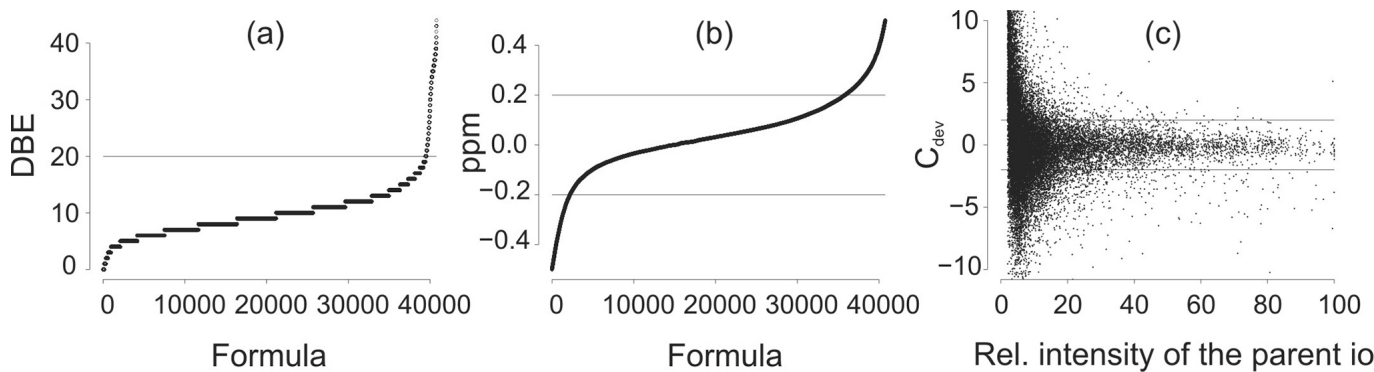

Figure 2. Validation of molecular formulas: (a) double bond equivalent (DBE) and (b) mass accuracy (in ppm) are displayed in increasing order for molecular formulas assigned in the complete data set. The quality of the peak magnitude ratio of a ${ }^{12} \mathrm{C}$-parent formula versus the corresponding ${ }^{13} \mathrm{C}$ daughter formula $\left({ }^{13} \mathrm{C}_{1}^{12} \mathrm{C}_{n-1}\right)$ was calculated as (c) the difference between the number of carbon atoms in the assigned formula and the number of carbon atoms estimated from the stable carbon isotope ratio $\left(\mathrm{C}_{\mathrm{dev}}\right.$, Koch et al., 2007). $\mathrm{C}_{\mathrm{dev}}$ is displayed versus the relative intensity of the parent ion.

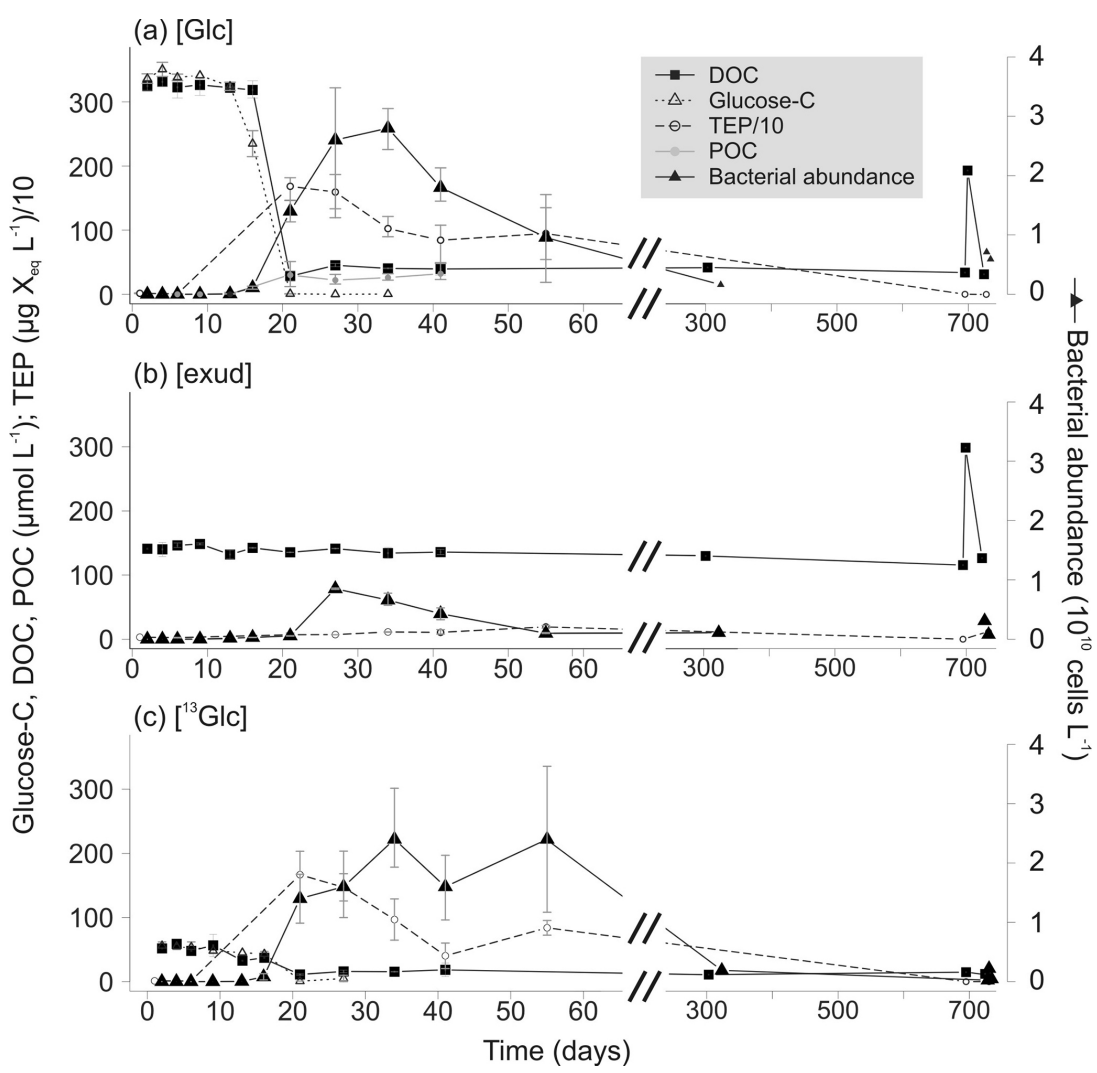

Figure 3. Concentration changes with time for the microbial degradation of (a) glucose [Glc], (b) algal-derived exudates [exud] and (c) ${ }^{13} \mathrm{C}$ labeled glucose $\left[{ }^{13} \mathrm{Glc}\right]$ treatments: dissolved organic carbon (DOC), particulate organic carbon (POC, only available for [Glc] treatments), glucose, transparent exopolymer particles (TEP) and bacterial abundance (bac, right $y$ axis). Error bars represent the range of values based on triplicates for [Glc] and duplicates for [exud] and [ $\left.{ }^{13} \mathrm{Glc}\right]$. On day $699, \sim 170 \mu \mathrm{M}$ glucose-C was added to one [Glc] and one [exud] bottle (singular samples).

${ }^{34} \mathrm{~S}$ because they only represented duplicates of the parent formulas for subsequent sample comparisons. Intensity weighted average (wa) molecular masses and element ratios were calculated from the normalized peak magnitudes. For formulas with a very high relative intensity, the iso- tope ratio provided an additional level of formula validation (Fig. 2c, Koch et al., 2007). 
Table 2. DOC concentrations for selected days, DOC consumed $\left(\mathrm{DOC}_{\mathrm{cons}}\right)$, minimum of non-labile DOC produced (calculated from the DOC concentration at day 27 minus day 21; DOC $_{\text {prod }}$ ), maximum POC concentration $\left(\mathrm{POC}_{\max }\right)$, maximum abundance of bacterial cells $\left(\mathrm{BA}_{\max }\right)$, cell carbon content $\left(=\mathrm{POC}_{\max } / \mathrm{BA}_{\max }\right)$, decay rate of non-labile DOC (period from day 27 until day 695$)$ and the estimated bacterial growth efficiency $\left(\mathrm{BGE}_{\mathrm{estim}}\right)$. Note - n.d. stands for not determined.

\begin{tabular}{|c|c|c|c|}
\hline & [Glc] & {$\left[{ }^{13} \mathrm{Glc}\right]$} & [exud] \\
\hline \multicolumn{4}{|l|}{ Average DOC concentrations $\left(\mu \mathrm{mol} \mathrm{C} \mathrm{L}{ }^{-1}\right)$ : } \\
\hline Day 2: initial substrate & $326 \pm 9$ & $53 \pm 2$ & $144 \pm 0$ \\
\hline Day 21: local minimum & $28 \pm 8$ & $11 \pm 1$ & $135 \pm 0$ \\
\hline Day 27: local maximum & $45 \pm 3$ & $16 \pm 2$ & $141 \pm 1$ \\
\hline Day 695: final concentration & $34 \pm 3$ & 15 & 115 \\
\hline DOC $_{\text {cons }}$ until day $21\left(\mu \mathrm{mol} \mathrm{CL^{-1 } )}\right.$ & $326^{\mathrm{a}}$ & $53^{\mathrm{a}}$ & 9 \\
\hline Minimum non-labile DOC $_{\text {prod }}\left(\mu \mathrm{mol} \mathrm{C} \mathrm{L}{ }^{-1}\right)$ & $17 \pm 6$ & $5 \pm 1$ & $6 \pm 0$ \\
\hline $\mathrm{POC}_{\max }\left(\mu \mathrm{mol} \mathrm{C} \mathrm{L}{ }^{-1}\right)$ & $30 \pm 20$ & n.d. & $12 \pm 4$ \\
\hline $\mathrm{BA}_{\max }\left(\right.$ cells L $\left.{ }^{-1}\right)$ & $2.8 \times 10^{10}$ & $2.4 \times 10^{10}$ & $8.5 \times 10^{9}$ \\
\hline Calculated cell carbon content (fg C cell $\left.{ }^{-1}\right)$ & 13 & n.d. & 17 \\
\hline Decay rate for non-labile DOC $\left(\mathrm{nmol} \mathrm{C} \mathrm{L}^{-1} \mathrm{yr}^{-1}\right)$ & 4 & 1 & 11 \\
\hline $\mathrm{BGE}_{\mathrm{estim}}\left(\mathrm{DOC}_{\text {cons }} /\left(\mathrm{DOC}_{\text {cons }}+\mathrm{POC}_{\max }\right)\right.$; unitless $)$ & 0.1 & n.d. & 0.6 \\
\hline
\end{tabular}

${ }^{a}$ Glucose was completely consumed after 21 days.

The degradation state was assessed using the degradation index $\left(I_{\mathrm{deg}}\right)$, as suggested in a recent study (Flerus et al., 2012). $I_{\text {deg }}$ can only be applied for PPL-extracted marine SPE-DOM analyzed with FT-ICR MS and electrospray ionization in negative mode. $I_{\mathrm{deg}}$ can be calculated from raw peak magnitudes of ten compounds which were found to correlate either positively $\left(\mathrm{POS}_{I_{\mathrm{deg}}}: \mathrm{C}_{13} \mathrm{H}_{18} \mathrm{O}_{7}\right.$, $\mathrm{C}_{14} \mathrm{H}_{20} \mathrm{O}_{7}, \mathrm{C}_{15} \mathrm{H}_{22} \mathrm{O}_{7}, \mathrm{C}_{15} \mathrm{H}_{22} \mathrm{O}_{8}, \mathrm{C}_{16} \mathrm{H}_{24} \mathrm{O}_{8}$ ) or negatively $\left(\mathrm{NEG}_{I_{\mathrm{deg}}}: \mathrm{C}_{17} \mathrm{H}_{20} \mathrm{O}_{9}, \mathrm{C}_{19} \mathrm{H}_{22} \mathrm{O}_{10}, \mathrm{C}_{20} \mathrm{H}_{22} \mathrm{O}_{10}, \mathrm{C}_{20} \mathrm{H}_{24} \mathrm{O}_{11}\right.$, $\mathrm{C}_{21} \mathrm{H}_{26} \mathrm{O}_{11}$ ) with $\Delta^{14} \mathrm{C}$ of marine DOC (Flerus et al., 2012; Eq. 1):

$$
I_{\mathrm{deg}}=\frac{\sum \text { magnitudes } \mathrm{NEG}_{I_{\mathrm{deg}}}}{\sum\left(\text { magnitudes } \mathrm{NEG}_{I_{\mathrm{deg}}}+\text { magnitudes } \mathrm{POS}_{I_{\mathrm{deg}}}\right)} .
$$

Higher $I_{\text {deg }}$ values correspond to a higher degree of degradation.

\subsection{Statistical analysis}

In the following, duplicates will be presented as mean values and their respective range and triplicates as means and standard deviation of the mean. For the FT-ICR MS data set, we assessed the molecular similarity between samples by applying cluster analyses and multidimensional scaling (MDS) based on Bray-Curtis similarity (Bray and Curtis, 1957) and untransformed normalized peak magnitudes (Software: "R" and Primer, Version 6).
Table 3. Total dissolved hydrolysable amino acids and their contribution to organic carbon (AA-C) in $\mu \mathrm{mol} \mathrm{L}^{-1}$ and percent of total DOC $(\%)$ in the [Glc], $\left[{ }^{13} \mathrm{Glc}\right]$ and [exud] treatments on day 4,16 and 41 .

\begin{tabular}{lrrrrrr}
\hline & \multicolumn{2}{c}{$[\mathrm{Glc}](n=3)$} & \multicolumn{1}{c}{$\left[{ }^{13} \mathrm{Glc}\right](n=2)$} & \multicolumn{2}{c}{$[$ exud] $(n=2)$} \\
\cline { 2 - 7 }$t(\mathrm{~d})$ & AA-C & $\%$ & AA-C & $\%$ & AA-C & $\%$ \\
\hline 4 & 0.7 & 0.0 & 1.9 & 0.5 & 0.7 & 0.3 \\
16 & 6.1 & 0.4 & 4.1 & 4.3 & 0.2 & 3.7 \\
41 & 4.3 & 2.3 & 3.4 & 3.1 & 0.7 & 5.6 \\
\hline
\end{tabular}

\section{Results}

\subsection{Substrate degradation and transformation}

Glucose was completely metabolized after 21 days in [Glc] and $\left[{ }^{13} \mathrm{Glc}\right]$ treatments (Fig. 3a, c). Simultaneously, nonglucose DOC was generated with concentrations reaching $45 \pm 3\left([\mathrm{Glc}]_{27}\right)$ and $16 \pm 2 \mu \mathrm{mol} \mathrm{C} \mathrm{L}{ }^{-1}\left(\left[{ }^{13} \mathrm{Glc}\right]_{27}\right.$; Table 2$)$. This microbially produced DOC will be termed "non-labile" in the following. The proportion of non-labile DOC formed in the $[\mathrm{Glc}]$ treatments relative to the original substrate-C can be calculated from the difference of the DOC concentration between day 21 and 27 (5-9\% of the initial glucose$\mathrm{C}$; Table 2) or by subtracting the average DOC blank in the controls $\left(16 \mu \mathrm{mol} \mathrm{DOC} \mathrm{L}{ }^{-1}\right)$ from the DOC concentration in a treatment ([Glc $]_{27}: 9 \%$ of the initial glucose-C). During the following 23 months, the non-labile DOC decreased at a rate of $4 \mu \mathrm{mol}$ and $1 \mu \mathrm{mol} \mathrm{C} \mathrm{L}{ }^{-1}$ year $^{-1}$ for $[\mathrm{Glc}]_{27-695}$ and $\left[{ }^{13} \mathrm{Glc}\right]_{27-695}$, respectively (Table 2). After 695 days, the remaining proportion of non-labile DOC in the [Glc] 695 treatments was $6 \%$ of the original substrate-C. The modification 
of DOM in the [exud] treatments could not be followed to the same detail because the added exudate consisted already of a complex mixture of substances preventing a quantification of substrate changes. The changes in DOC concentration in the [exud] treatments were small during the exponential growth of bacteria. After the exponential phase, the DOC in [exud] ${ }_{27-695}$ decreased at a rate of $11 \mu \mathrm{mol} \mathrm{CL}^{-1}$ year $^{-1}$, faster than in the [Glc] treatments (Fig. 3b). Particulate organic carbon (POC) concentration in the [Glc] treatments reached its maximum at 21 days $\left(30 \pm 20 \mu \mathrm{mol} \mathrm{C} \mathrm{L}^{-1}\right)$. Since the values reached the limits of precision $(\sim 5 \%$ precision $)$, the errors were relatively large. For the [exud] and $\left[{ }^{13} \mathrm{Glc}\right]$ treatments POC was much lower. Except for the maximum concentration in [exud] $]_{41}\left(12 \pm 4 \mu \mathrm{mol} \mathrm{C} \mathrm{L}{ }^{-1}\right)$, POC could not be quantified in these treatments.

After 699 days glucose was added to one [Glc $]_{699}$ and one [exud] ${ }_{699}$ treatment to track potential priming effects (Fig. 3). Twenty-five days later, the DOC concentration was similar or slightly above the value before the glucose addition in both bottles and TEP had increased slightly to 100 and $109 \mu \mathrm{g}$ $X_{\text {eq }} \mathrm{L}^{-1}$ in [Glc] and [exud], respectively.

For selected samples, total hydrolysable amino acids were determined. The proportion of organic carbon derived from amino acids (AA-C) increased for [Glc] and $\left[{ }^{13} \mathrm{Glc}\right]$ and decreased in [exud] treatments at day 16 and increased again towards the end of the first phase of the experiment (Table 3). The relative increase of AA-C with incubation time coincided with the average increase of organic nitrogen in the mass spectrometry data set (see Sect. 3.6). The amino acid composition was dominated by glycine, glutamic acid/glutamine and leucine. Most other amino acids were near or below the limit of detection.

\subsection{Controls}

Four controls provided experimental validation (Table 1). The background control ${ }^{\mathrm{c}}$ [none] had an average DOC concentration of $15 \pm 3 \mu \mathrm{mol} \mathrm{DOCL}^{-1}$ during the entire incubation period (Fig. 4). The DOC concentration of the sterile background control ${ }^{\mathrm{sc}}$ [none] was slightly higher $\left(23 \pm 12 \mu \mathrm{mol} \mathrm{DOC} \mathrm{L}{ }^{-1}\right)$. Both values were near the limit of quantitation. The DOC concentration of the inoculum was $43 \pm 1 \mu \mathrm{mol} \mathrm{L}-1$, but after the $1: 49$ dilution with the medium, it contributed only marginally to DOC.

No temporal change in DOC (Fig. 4), nutrient or TEP concentration was observed during the first 55 days in the two background controls ${ }^{\mathrm{sc}}$ [none] and ${ }^{\mathrm{c}}$ [none] or in the two sterile substrate controls, ${ }^{\mathrm{sc}}[\mathrm{Glc}]$ and ${ }^{\mathrm{sc}}$ [exud]. The bacterial abundance increased slightly with time, but remained $2-3$ orders of magnitude below the abundance of the substrate treatments (compare Fig. 3). (a) DOC concentration

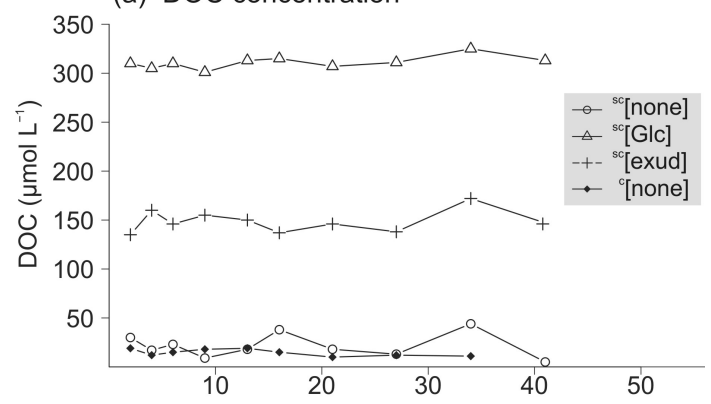

(b) Bacterial abundance

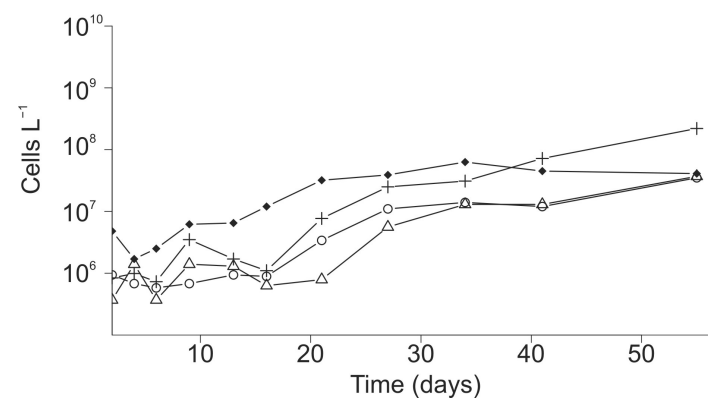

Figure 4. Control samples: DOC concentration and bacterial cell abundance during the incubation period.

\subsection{Inorganic nutrients}

During the entire experiment, nutrient concentrations were sufficiently high to prevent the limitation of bacterial growth (Fig. 5). Due to the addition of the algal-derived DOM solution, the initial concentrations of nitrate, nitrite and phosphate were higher $\left(\sim 150 \mu \mathrm{mol} \mathrm{L}^{-1}, \sim 9 \mu \mathrm{mol} \mathrm{L}^{-1}\right.$ and $\sim 10 \mu \mathrm{mol} \mathrm{L}^{-1}$, respectively) in the [exud] compared to the $[\mathrm{Glc}]$ and $\left[{ }^{13} \mathrm{Glc}\right]$ treatments. The bacterial inoculum did not add detectable amounts of nutrients to the incubations.

Ammonium decreased from about 55 to $28 \mu \mathrm{mol} \mathrm{L}^{-1}$ in the $[\mathrm{Glc}]$ and $\left[{ }^{13} \mathrm{Glc}\right]$ samples, slightly increased at 41 days and decreased again at 55 days whereas it remained almost constant at $60 \mu \mathrm{mol} \mathrm{L}-1$ in the [exud] treatments. Nitrate, nitrite and phosphate remained almost constant in all treatments.

\subsection{Bacterial growth dynamics}

Bacterial cell growth started slowly with a long lag phase (16 days) which may be attributed to the low incubation temperature $\left(0^{\circ} \mathrm{C}\right)$. Exponential growth and pronounced changes in substrate concentration and in TEP formation occurred between day 16 and day 21 in the [Glc] and $\left[{ }^{13} \mathrm{Glc}\right]$ treatments and slightly later, between day 21 and day 26, in the [exud] treatments (Fig. 3). Despite the fact that the initial DOC concentration in [Glc] was 6.5 times higher than in $\left[{ }^{13} \mathrm{Glc}\right]$, the maximum bacterial cell number was only slightly lower in $\left[{ }^{13} \mathrm{Glc}\right]_{34}$ compared to $[\mathrm{Glc}]_{34}$ (Table 2 ). In 

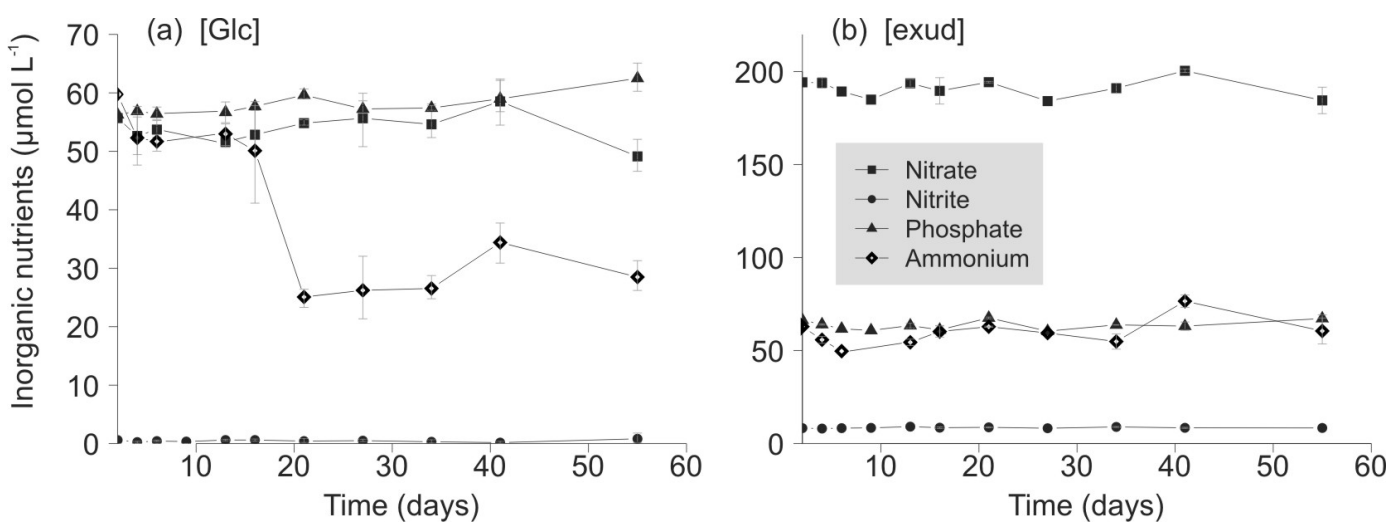

Figure 5. Inorganic nutrients: concentration of nitrite, ammonium, phosphate and nitrate during the incubation period. Changes are displayed as averages for (a) [Glc] treatments $(n=3)$ and (b) [exud] treatments $(n=2)$. Error bars represent the range of values. Changes in [ $\left.{ }^{13} \mathrm{Glc}\right]$ treatments (not shown) were almost identical to [Glc] samples.

contrast, the maximum bacterial cell number in [exud $]_{27}$ was 3.3 times lower than in $[\mathrm{Glc}]_{34}$.

Not only were the maximal bacterial cell concentrations in [exud] lower than in [Glc] but the cells were also slightly smaller. In [Glc] $3497 \%$ of bacteria were $>2 \mu \mathrm{m}$, whereas only $92 \%$ were that large in [exud] $]_{34}$. After 323 days, $83 \%$ and $63 \%$ of bacteria were considered large in $[\mathrm{Glc}]_{323}$ and [exud] $]_{323}$, respectively. A rough estimate of the carbon content of a microbial cell was derived by dividing the POC concentration for [Glc] $]_{21-41}$ and [exud] $]_{27-41}$ (30 and $12 \mu \mathrm{mol}$ POC L $^{-1}$, respectively) by the maximum bacterial abundance $\left(2.8 \times 10^{10}\right.$ and $0.85 \times 10^{10}$ cells L $^{-1}$, respectively). This resulted in an average cell carbon content of $13 \mathrm{fg} \mathrm{C}$ cell $^{-1}$ for [Glc] and $17 \mathrm{fg} \mathrm{C}$ cell $^{-1}$ for [exud].

The bacterial growth efficiency (BGE) can be calculated from the ratio of bacterial production (BP) to respiration (BR) using Eq. (2) (del Giorgio and Cole, 1998):

$\mathrm{BGE}=\mathrm{BP} /(\mathrm{BP}+\mathrm{BR})$.

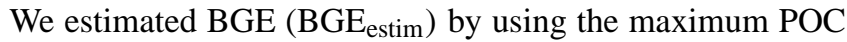
concentration $\left(\mathrm{POC}_{\max }\right)$ and the total amount of $\mathrm{DOC}$ consumed ( $\mathrm{DOC}_{\mathrm{cons}}$; Eq. 3, Table 2). The estimate is based on the assumption that all of the POC produced is derived from bacterial biomass or colloids formed by bacteria.

$\mathrm{BGE}_{\text {estim }}=\mathrm{POC}_{\max } /\left(\mathrm{POC}_{\max }+\mathrm{DOC}_{\text {cons }}\right)$

The estimated BGE was comparable in the treatments which contained glucose (0.1) and substantially higher in the [exud] treatments $(0.6)$.

Concentrations of flagellates were below detection in all treatments, suggesting that grazing did not significantly impact microbial dynamics.

\subsection{Transparent exopolymer particles (TEP)}

The concentration of TEP was highest during the exponential growth in $[\mathrm{Glc}]_{21}$ and $\left[{ }^{13} \mathrm{Glc}\right]_{21}(1683 \pm 189$ and
$1667 \pm 518 \mu \mathrm{g} X_{\text {eq }} \mathrm{L}^{-1}$, respectively; Fig. 3). TEP production in [exud] treatments increased steadily until day 55 $\left(193 \pm 31 \mu \mathrm{g} X_{\mathrm{eq}} \mathrm{L}^{-1}\right)$, but remained an order of magnitude lower than in [Glc]. Although the bacterial abundance (BA) and TEP concentration were not correlated, the TEP/BA ratio at the maximum of the bacterial abundance was similar for $[\mathrm{Glc}]_{27}$ and $\left[{ }^{13} \mathrm{Glc}\right]_{27}\left(61\right.$ and $90 \mathrm{fg} X_{\text {eq }}$ cell ${ }^{-1}$, respectively). In contrast, this ratio was lower at $8 \mathrm{fg} X_{\mathrm{eq}}$ cell $^{-1}$ in the $[\text { exud }]_{27}$ treatments. Although TEP and DOC were also not significantly correlated within each treatment, the TEP / DOC ratio was appreciably higher in $[\mathrm{Glc}]_{27}$ and ${ }^{13} \mathrm{Glc}_{27}$ (35 and $93 \mu \mathrm{g} X_{\text {eq }} \mu \mathrm{mol}^{-1} \mathrm{C}^{-1}$, respectively) compared to [exud] $]_{27}\left(1 \mu \mathrm{g} X_{\text {eq }} \mu \mathrm{mol} \mathrm{C}^{-1}\right)$.

After the maximum TEP concentration was reached in the glucose incubations $[\mathrm{Glc}]_{21}$ and $\left[{ }^{13} \mathrm{Glc}\right]_{21}$, TEP quickly decreased by about $25 \mu \mathrm{g} X_{\mathrm{eq}} \mathrm{L}^{-1} \mathrm{~d}^{-1}$ towards day 55. In the [exud] treatments, TEP increased until day $55(\sim 4 \mu \mathrm{g}$ $X_{\text {eq }} \mathrm{L}^{-1} \mathrm{~d}^{-1}$ ). At the end of the experiment, on day 695, TEP was below detection in all treatments.

\subsection{Molecular formulas determined by ultrahigh resolution MS}

The average molecular characteristics derived from ultrahigh resolution mass spectra of the solid-phase extracted DOM are presented in Table 4 . The spectrum of $\left[{ }^{13} \mathrm{Glc}\right] 70$ was different from all other spectra: it generally showed fewer peaks but several additional peak clusters in the mass range above $600 \mathrm{~m} / z$. The total peak magnitude was 2-3 times lower compared to all other samples. We attributed this to analytical reasons (salt residues) and therefore excluded this spectrum from the subsequent molecular comparisons.

To evaluate the data quality and reproducibility we compared ${ }^{\mathrm{sc}}$ [none], ${ }^{\mathrm{c}}$ [none] and ${ }^{\mathrm{Sc}}$ [Glc], which only differed by the presence/absence of glucose. These controls were highly similar based on the number of assigned peaks, the $I_{\mathrm{deg}}$, and the peak magnitude weighted average element 
Table 4. Mean data of the molecular characterization via FT-ICR MS: number of identified peaks in the spectrum (signal-to-noise ratio $\geq 4$ ), number of formulas assigned $(n)$, peak magnitude weighted averages (wa) of the molecular mass (Mass $\mathrm{wa}_{\mathrm{wa}}$ ), double bond equivalent $\left(\mathrm{DBE}_{\mathrm{wa}}\right)$, oxygen-to-carbon ratio $\left(\mathrm{O} / \mathrm{C}_{\mathrm{wa}}\right)$, hydrogen-to-carbon ratio $\left(\mathrm{H} / \mathrm{C}_{\mathrm{wa}}\right)$, carbon-to-nitrogen ratio $\left(\mathrm{C} / \mathrm{N}_{\mathrm{wa}}\right)$ and carbon-to-sulfur ratio $\left(\mathrm{C} / \mathrm{S}_{\mathrm{wa}}\right)$. The degradation index $\left(I_{\mathrm{deg}}\right)$ indicates the relative state of degradation of marine SPE-DOM using electrospray ionization in negative mode (Flerus et al., 2012). IOS (\%; island of stability, Lechtenfeld et al., 2014) is the total relative peak magnitude of the most stable molecular formulas compared to the total peak magnitude of all $\mathrm{CHO}$ containing molecular formulas.

\begin{tabular}{|c|c|c|c|c|c|c|c|c|c|c|}
\hline Sample & Peaks $(n)$ & $n$ & Mass $_{w a}$ & $\mathrm{DBE}_{\mathrm{wa}}$ & $\mathrm{O} / \mathrm{C}_{\mathrm{wa}}$ & $\mathrm{H} / \mathrm{C}_{\mathrm{wa}}$ & $\mathrm{C} / \mathrm{N}_{\mathrm{wa}}$ & $\mathrm{C} / \mathrm{S}_{\mathrm{wa}}$ & $I_{\mathrm{DEG}}$ & IOS $(\%)$ \\
\hline $\left.\mathrm{sc}_{[\text {none }}\right]_{70}$ & 11941 & 2183 & 415 & 8.7 & 0.437 & 1.260 & 50.5 & 239 & 0.81 & 50 \\
\hline${ }^{\mathrm{c}}[\text { none }]_{70}$ & 13618 & 2289 & 426 & 8.9 & 0.443 & 1.254 & 47.7 & 226 & 0.81 & 52 \\
\hline${ }^{\mathrm{sc}}[\mathrm{Glc}]_{70}$ & 12480 & 2232 & 422 & 8.9 & 0.440 & 1.250 & 47.9 & 239 & 0.81 & 51 \\
\hline$[\mathrm{Glc}]_{70}$ & 14027 & 3404 & 449 & 8.9 & 0.433 & 1.296 & 39.2 & 175 & 0.85 & 43 \\
\hline [Glc] 695 & 13591 & 2930 & 416 & 8.8 & 0.438 & 1.240 & 32.6 & 103 & 0.80 & 50 \\
\hline$[\mathrm{Glc}]_{695}$ & 13643 & 2565 & 420 & 8.7 & 0.439 & 1.260 & 37.9 & 118 & 0.82 & 50 \\
\hline$\left[{ }^{13} \mathrm{Glc}\right]_{695}$ & 13357 & 2350 & 428 & 8.9 & 0.455 & 1.250 & 41.4 & 192 & 0.83 & 53 \\
\hline${ }^{\mathrm{sc}}[\text { exud }]_{70}$ & 15668 & 3082 & 412 & 8.2 & 0.454 & 1.291 & 45.7 & 182 & 0.52 & 40 \\
\hline$[\text { exud }]_{70}$ & 13962 & 4424 & 494 & 9.9 & 0.462 & 1.269 & 33.8 & 153 & 0.70 & 36 \\
\hline$[$ exud] 695 & 14040 & 4677 & 442 & 9.0 & 0.459 & 1.261 & 35.5 & 155 & 0.61 & 39 \\
\hline
\end{tabular}

ratios (Table 4). The average coefficient of variation for their relative peak magnitude (as an indicator for reproducibility) was $7.9 \%$. The reproducibility for larger peaks ( $>40 \%$ relative peak magnitude) was better and resulted in a coefficient of variation of only $2.6 \%$. The average peak magnitude weighted ratios for the three replicates were for $\mathrm{O} / \mathrm{C}_{\mathrm{wa}}=0.440 \pm 0.003, \mathrm{H} / \mathrm{C}_{\mathrm{wa}}=1.255 \pm 0.005$, $\mathrm{C} / \mathrm{N}_{\mathrm{wa}}=48.7 \pm 1.6$ and $\mathrm{C} / \mathrm{S}_{\mathrm{wa}}=234.8 \pm 7.5$. They were thus considered to be process replicates and their average peak magnitudes were used as a reference for the comparison with [Glc] treatments. ${ }^{\mathrm{sc}}$ [exud] was used as the control for the [exud] treatments.

The mass spectra of the different treatments revealed characteristic molecular differences particularly between the [Glc] and [exud] samples (Table 4). The [exud] spectra were characterized by an almost Gaussian peak distribution typical for natural organic matter (Fig. 6). In contrast, all [Glc] and $\left[{ }^{13} \mathrm{Glc}\right]$ treatments showed spectra with several additional peaks which did not match with the typical DOM peak magnitude distribution. The number of peaks and assigned molecular formulas in the [exud] spectra was higher compared to [Glc] treatments. The average molecule in the [exud] samples was larger and contained, compared to the number of $\mathrm{C}$ atoms, more oxygen and nitrogen. In addition, the [exud] treatments showed a lower $I_{\mathrm{deg}}$ value (less degraded) than [Glc] treatments. $I_{\text {deg }}$ in the sterile control ${ }^{\mathrm{sc}}$ [exud] indicated that the original algae-derived DOM was more labile than the background DOM introduced by the inoculum in ${ }^{\mathrm{sc}}$ [none], ${ }^{\mathrm{c}}$ [none] and ${ }^{\mathrm{sc}}$ [Glc].

Incubation time also had an influence on the molecular composition. For [exud] treatments, the number of peaks assigned with a molecular formula increased with time whereas the total number of peaks in the spectrum slightly decreased. In [Glc] samples, the number of peaks and molecular formu- las increased at 70 days and decreased at 695 days. For all treatments, $I_{\mathrm{deg}}$ was higher after 70 days and decreased again at 695 days. All treatments showed, compared to the number of $\mathrm{C}$ atoms, an increase in organic nitrogen and organic sulfur after microbial incubation. The total relative peak magnitude of the most stable compounds (island of stability, IOS, Lechtenfeld et al., 2014) compared to the total peak magnitude of all CHO compounds was calculated (Table 4). All treatments showed a lower relative contribution of IOS compounds after 70 days and a higher contribution towards 695 days.

The inoculum, which was added to each treatment, introduced a small proportion of refractory compounds (Antarctic surface water, $1: 49$ dilution), which needs to be considered for the molecular level comparison. Also, algae-derived DOM in the [exud] treatments contained a background of organic compounds derived from the culture medium. To avoid artifacts in data processing, molecular differences between treatments and controls were explored based on relative peak magnitude ratios: each mass peak in a substrate treatment was compared to the respective peak in the control treatment. Therefore, we used the relative peak magnitudes for each mass peak (= molecular formula) to calculate the peak magnitude ratio Peak sample $_{\text {e }} /\left(\mathrm{Peak}_{\mathrm{sample}}+\mathrm{Peak}_{\mathrm{control}}\right)$. A peak magnitude ratio of 1 represents peaks which were predominant in the sample treatment (red colors, Fig. 6), a value near zero represents peaks which were conspicuous in the control (blue colors) and a relative peak magnitude of 0.5 denotes unchanged relative peak magnitudes (white color). In addition, we selected all peaks which were unique in the substrate treatments compared to their respective control (circles and numbers, Fig. 6). Only a few formulas $(<30)$ uniquely occurred in the controls compared to the substrate incubations. The only exception was the ${ }^{\mathrm{sc}}$ [exud] control, in 
(a) $[\mathrm{Glc}]$

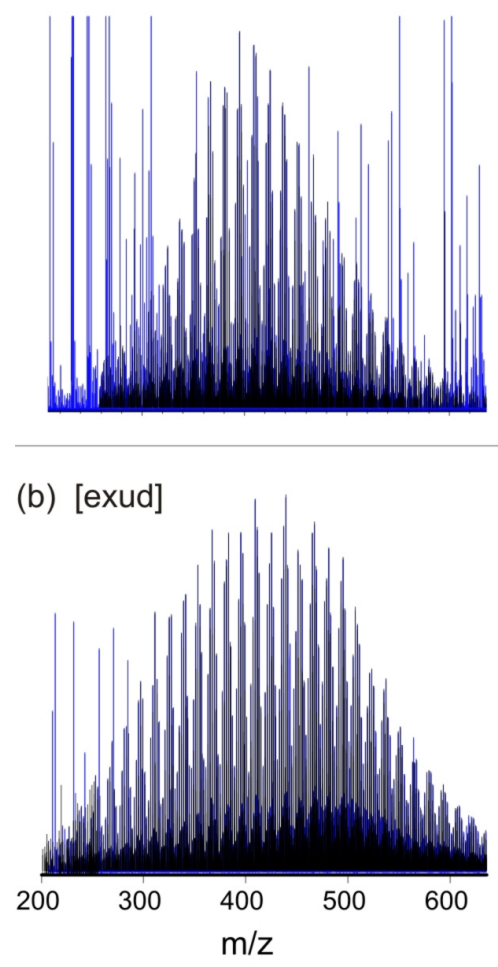

70 days

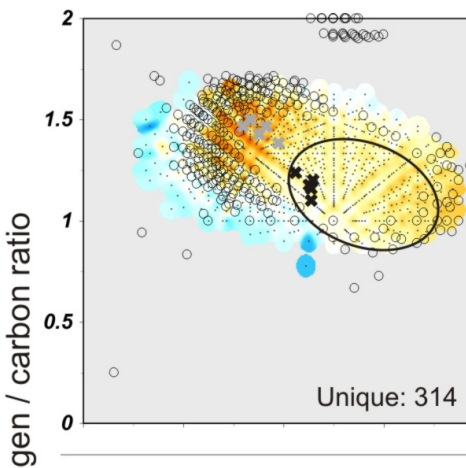

들

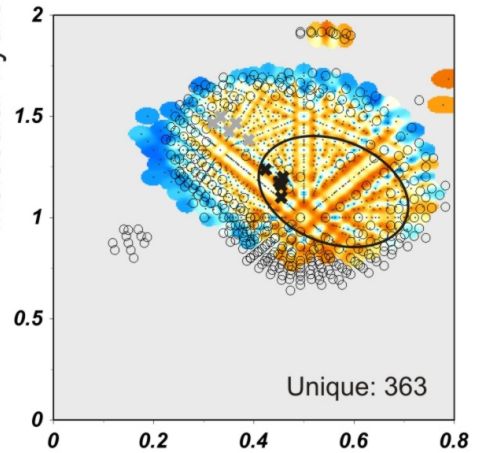

Molecular oxygen / carbon ratio
695 days

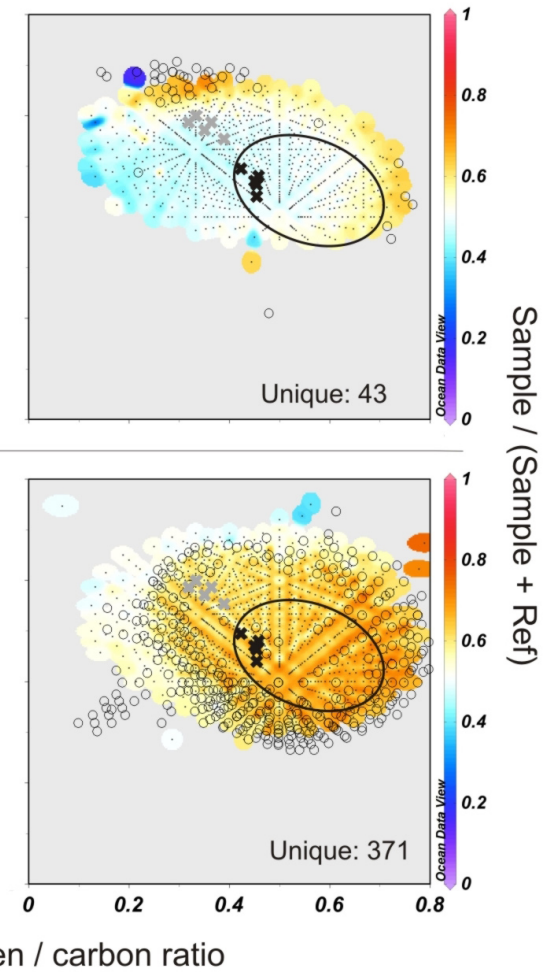

Figure 6. FT-ICR mass spectra of the solid-phase extracts of microbially degraded (a) glucose [Glc] and (b) algal-exudate [exud] after 70 and 695 days of incubation. Left panel: measured spectra (in blue) and reconstructed spectra based on all identified molecular formulas containing C, H and O (in black). Right panel: van Krevelen plots represent all CHO molecular formulas. Formulas which occurred uniquely in the samples and not in the controls (average of ${ }^{\mathrm{sc}}$ [none], ${ }^{\mathrm{sc}}$ [Glc], ${ }^{\mathrm{c}}$ [none] for [Glc] and ${ }^{\mathrm{sc}}$ [exud] for [exud]) are marked with a black circle. All other formulas are represented by the color which reflects the ratio of the peak magnitude in the sample versus the respective magnitude in the controls (Sample / (Sample + Ref)). The black circle represents the area in which molecular formulas with the highest residence times in the ocean would be displayed (according to Lechtenfeld et al., 2014; island of stability). The crosses represent those 10 peaks which are used to calculate the degradation state of marine DOM (Flerus et al., 2012; $I_{\mathrm{deg}}$ ): grey crosses represent molecular formulas which are labile; black crosses represent refractory molecular formulas.

which we detected 173 unique formulas which were absent in the $[$ exud] 70 treatment.

For data representation, we used the van Krevelen diagram (van Krevelen, 1950; Kim et al., 2003; Fig. 6). All formulas which consisted of $\mathrm{C}, \mathrm{H}$, and $\mathrm{O}$ were displayed with respect to their molecular hydrogen / carbon and oxygen / carbon ratio. Saturated and reduced compounds appear in the upper left whereas unsaturated and oxidized substances appear in the lower right of the van Krevelen diagram.

Most molecular changes occurred in the boundary area of the patch in the diagram (indicated by the red color and circles in Fig. 6). For the [Glc] incubations, in particular, the strongest peak magnitude increase occurred outside of the center region in which the most persistent marine molecular formulas would be displayed (as identified in Lechtenfeld et al., 2014, Fig. 6, black ellipse). However, after 695 days, these changes were less pronounced, indicating that the material became more similar compared to the control samples. In the [exud] treatments, a relative loss of peak magnitude outside the center of the patch was detected particularly after 70 days (blue colors in Fig. 6) but relative peak magnitude gains also occurred in the center where compounds with longer ocean residence times are expected.

A hierarchical cluster analysis and multidimensional scaling (MDS) was applied to summarize the molecular differences between the treatments (Fig. 7). The analysis was based on untransformed relative peak magnitudes and did not include formulas containing ${ }^{13} \mathrm{C}$. Although we expected that the ${ }^{13} \mathrm{C}$-label in the $\left[{ }^{13} \mathrm{Glc}\right]$ treatments would be detectable in the non-labile DOM pool, enrichment of ${ }^{13} \mathrm{C}$ compared to the unlabeled controls and treatments ${ }^{\mathrm{c}}[\mathrm{Glc}],{ }^{\mathrm{sc}}[\mathrm{Glc}]$ and [Glc] was not found. This result was verified by an additional cluster analysis which included the ${ }^{13} \mathrm{C}$-isotopes: the analysis yielded identical results as the approach in absence of the stable carbon isotopes (data not shown).

The degree of similarity between samples is indicated by the similarity scale in the cluster analyses (Fig. 7, left panel). A similarity value of 100 would be derived from two samples 

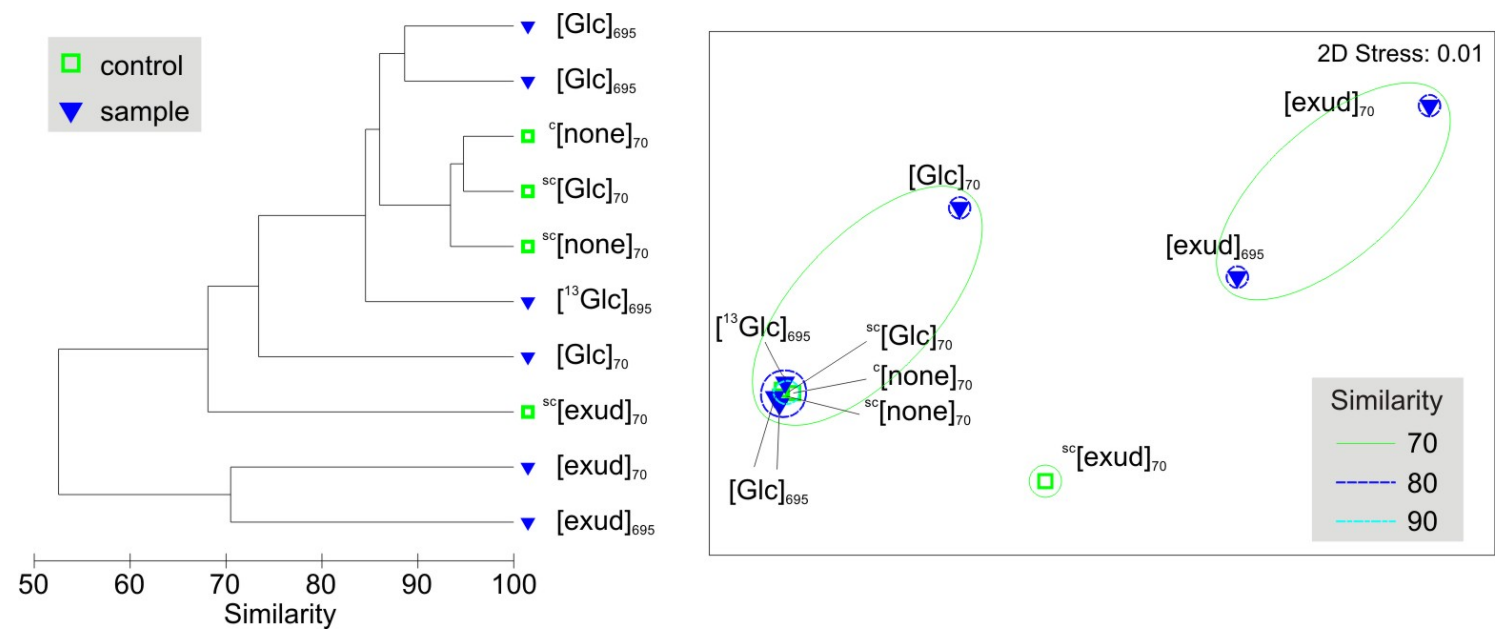

Figure 7. Sample comparison based on hierarchical cluster analysis (left panel) and multidimensional scaling (right panel). Relative peak magnitudes of all identified molecular formulas (isotopologues excluded) were compared based on Bray-Curtis similarity and group average clustering.

with identical relative intensities for all mass peaks in the spectrum. In the MDS analysis (Fig. 7, right panel), the similarity is expressed by the distance between samples in the MDS plot. A stress value of $<0.03$ indicates an excellent representation of sample similarities in a two-dimensional representation. In addition, samples are grouped according to three levels of similarity derived from the cluster analysis.

An additional confirmation of good data reproducibility of the measurements was provided by the high degree of similarity between the duplicates of the $[\mathrm{Glc}]_{695}$ treatments (Fig. 7). In agreement with the results of the average parameters (Table 4), the three controls ${ }^{\mathrm{sc}}$ [none], ${ }^{\mathrm{sc}}$ [Glc] and ${ }^{\mathrm{c}}$ [none] showed the most similar molecular patterns (Fig. 7). These controls were most similar to the $[\mathrm{Glc}]_{695}$ and $\left[{ }^{13} \mathrm{Glc}\right]_{695}$ treatments whereas $[\mathrm{Glc}]_{70}$ was dissimilar. The [exud] treatments formed a cluster most dissimilar from all other samples and were similar to the respective control ${ }^{\mathrm{sc}}[\text { exud }]_{70}$.

\section{Discussion}

According to a recent definition, marine DOC may be classified as "labile" if it is removed on timescales of hours to days, as "semi-labile" if the lifetime reaches $\sim 1.5$ years and as "refractory" if it persists for 16000 years or longer (Hansell, 2013). In our study, the concentration of background DOC persisted until the end of the 2-year experiment, and could therefore be termed semi-labile. However, using only bulk DOC concentrations, we cannot decide whether the material produced in our experiment could persist on even longer timescales (refractory DOM). In fact, DOM can also be regarded as a dynamic continuum of compounds of variable persistence and degradability (Flerus et al., 2012). Therefore, the DOC that was microbially formed in the experiment will be called non-labile in this context.
DOM dynamics in [Glc] treatments could be followed in greater detail than in [exud] samples: in the [Glc] treatments the changes of the original substrate (glucose) could be directly monitored and, in this way, labile and non-labile DOC could be distinguished. In the [exud] treatments, we only observed the gross DOC change without the option to differentiate between substrate and non-labile DOC.

\subsection{Bulk DOM changes: microbial consumption and transformation of organic carbon}

In the $[\mathrm{Glc}]$ and $\left[{ }^{13} \mathrm{Glc}\right]$ treatments, microbial growth was most pronounced between day 16 and 27 and glucose was completely consumed by day 21 , when DOC showed a minimum. This suggests that the glucose was utilized rapidly once bacteria responded and non-labile DOM was generated, evident in our experiment as an increase of DOC after the consumption of glucose. A similar shift from a mixture of labile DOM to non-labile DOM is assumed to have occurred between day 16 and 21 in the [exud] treatments but it is less well resolved. The fraction of labile DOM was small in the original [exud] as DOC decreased by only $6 \%$. This suggests that the added algal exudates were already degraded when the experiment started. Obviously, the most labile fraction of the exudation products was utilized immediately upon their release or during storage, before our experiment. Inorganic nutrients were present in sufficient amounts throughout our experiment and therefore did not limit microbial growth and substrate degradation. Apart from the changes we observed for the ammonium concentration in the $[\mathrm{Glc}]$ and $\left[{ }^{13} \mathrm{Glc}\right]$ treatments, we assume that changes in nutrient concentrations were below detection. The DOC net consumption of $9 \mu \mathrm{mol} \mathrm{DOC} \mathrm{L}{ }^{-1}$ in the [exud] treatments in the exponential 
growth phase (Table 3 ) would require less than $\sim 2 \mu \mathrm{mol} \mathrm{L}^{-1}$ inorganic nitrogen and far less phosphate.

The rapid initial uptake of glucose and the production of non-labile DOC is consistent with findings of earlier studies (e.g. Brophy and Carlson, 1989; Ogawa et al., 2001; Gruber et al., 2006; Kawasaki and Benner, 2006) and the concept of the microbial carbon pump (Jiao et al., 2010; Benner and Herndl, 2011). About 5-9\% of the initial glucose carbon persisted as non-labile DOC in our experiment. This was comparable to a proportion of $5 \%$ (incubation at $22^{\circ}$ to $28^{\circ} \mathrm{C}$ ) found by Ogawa et al. (2001). Gruber et al. (2006) incubated much higher glucose concentrations resulting in a higher absolute non-labile DOC concentration, but a similar proportion of remaining DOC $\left(4.4 \%\right.$; incubation at $\left.20^{\circ} \mathrm{C}\right)$. The slightly larger fraction of non-labile DOC in our experiment may be explained by the much lower incubation temperature of $0^{\circ} \mathrm{C}$. A positive correlation between the amount of the labile DOM and temperature was previously found (Lonborg et al., 2010).

The dynamics of substrate consumption differed substantially between [Glc] and [exud] treatments: in [Glc] treatments, bacteria quickly metabolized $100 \%$ of the glucose, at a decay rate of $\sim 50 \mu$ mol glucose-C $\mathrm{L}^{-1} \mathrm{~d}^{-1}$ (day 16-21) and produced TEP and non-labile DOC. A comparison between $\left[{ }^{13} \mathrm{Glc}\right]$ and $[\mathrm{Glc}]$ suggests that the bacterial cell abundance and the amount of TEP produced were independent of the available glucose concentration. In the [exud] treatments, the production of TEP and the microbial biomass was smaller than in the [Glc] treatments, and as much as $80 \%$ of the initial DOC was still present even after 2 years of incubation, indicating that only $20 \%$ of the algae exudate was labile. The decay rate of the remaining non-labile [exud] DOM was, however, faster compared to the decay of the non-labile DOM generated from glucose. This suggests that the treatments still differed in their composition and biodegradability of the non-labile DOM fraction. On a molecular formula level, this is supported by the lower $I_{\mathrm{deg}}$ value in [exud] than [Glc] before and after incubation.

It is conspicuous that, although the amount of initial carbon consumed differed strongly between the three treatments, the bacterial cell abundance in all treatments was on the same order of magnitude. Since we can rule out additional carbon fixation by other autotrophic organisms, three explanations appear possible: (i) additional carbon was fixed by chemoautotrophic bacteria, (ii) the size and carbon content of the bacterial cells and (iii) the bacterial growth efficiency differed between treatments.

A substantial uptake of ammonium was observed in the [Glc] and $\left[{ }^{13} \mathrm{Glc}\right]$ treatments but not in the controls, indicating that ammonium was the preferred source of nitrogen for microbial growth. However, neither a parallel increase in nitrate, which would be indicative for chemoautotrophy, nor a decrease in ammonium in the [exud] treatments was observed, where cell production was high compared to carbon utilization. Therefore, chemoautotrophy is unlikely to have contributed to organic carbon production.

Although we did not include microbial community analyses, it is to be expected that the composition of the bacterial communities developed differently due to the different substrates and also changed over time. The microscopic observations indicated that $8 \%$ of the bacterial cells in the [exud] $]_{34}$ treatments were smaller in size compared to the [Glc] samples. The average carbon content of bacteria were similar in [exud] and [Glc] treatments (17 vs. $13 \mathrm{fg} \mathrm{C}^{-1} \mathrm{cell}^{-1}$ ) and both were in the range of marine bacteria (e.g. $12.4 \pm 6.3 \mathrm{fg}$ $\mathrm{C} \mathrm{cell}^{-1}$, Fukuda et al., 1998). The estimated BGE was much higher in the [exud] compared to the [Glc] treatments: BGE in the [exud] samples resembled the high values measured in situ in the Weddell Sea (Bjornsen and Kuparinen, 1991; del Giorgio and Cole, 1998) and in incubations using algal exudates (del Giorgio and Cole, 1998; Cavalli et al., 2004). Bacterial growth efficiency for the glucose treatments was much lower and in agreement with low values for highly oxidized and nitrogen-poor labile substrates (Vallino et al., 1996; del Giorgio and Cole, 1998). For our experiment, the differences in BGE of the microbial population accurately reflected the mismatch between the carbon utilization and the associated bacterial growth.

We hypothesized that the bioavailability of the produced non-labile DOM could be increased by the addition of labile substrates (co-metabolism, priming effect; Horvath, 1972; Bianchi, 2011). However, the addition of glucose after 699 days in our experiment did not enhance degradation of the non-labile material. Instead, the added glucose was quickly consumed and the concentration of non-labile DOC remained constant or slightly increased. Thus, for our setup, we can reject the hypothesis that the addition of glucose enhances degradation of non-labile material. The slight increase of non-labile DOM after glucose addition rather supports the idea that the formation of non-labile DOM is dependent on the substrate concentration. Alternatively, the increase might also be explained by the degradation of the twoyear-old DOC and a subsequent overcompensation of newly formed non-labile DOC due to the glucose addition.

It must be considered that the artificial seawater medium did not contain trace elements because the standard trace element (and vitamin) solutions would have introduced additional organic compounds (such as ethylenediaminetetraacetic acid; EDTA). However, the priming experiment suggests that the microbial community was not generally trace-element-limited because microbial growth and degradation after glucose addition was still possible. Nevertheless, trace element limitation might have prevented or slowed down degradation of the non-labile DOM.

TEP were formed during the experiment, particularly from bacteria growing on glucose and less from those growing on the algae-DOM. Bacteria are known to form TEP or their precursors (Stoderegger and Herndl, 1999; Sugimoto et al., 2007). Due to their affinity to other particles (stickiness), 
TEP are important for the biological pump (Alldredge et al., 1993; Passow et al., 1994; Logan et al., 1995). The formation of aggregates increases the sinking velocities of particles, allowing a larger fraction of carbon to reach the deep ocean before degradation. Our experimental results suggest, however, that the role of TEP for the biological pump could be limited by its residence time. The average TEP degradation rate in the [Glc] treatments was $25 \mu \mathrm{g} X_{\mathrm{eq}} \mathrm{L}^{-1} \mathrm{~d}^{-1}$. The contribution of organic carbon in xanthan gum monomers $\left(\mathrm{C}_{35} \mathrm{H}_{49} \mathrm{O}_{29}\right)$ is $45 \%(w: w)$. For a rough estimate of the carbon balance, we can assume that xanthan gum monomers are representative for TEP produced in the treatment. Hence, the respective TEP degradation rate would be $11 \mu \mathrm{g}$ TEP$\mathrm{CL}^{-1} \mathrm{~d}^{-1}$ or $\sim 1 \mu \mathrm{mol}$ TEP-C $\mathrm{L}^{-1} \mathrm{~d}^{-1}$. The comparison to typical POC concentrations in the surface ocean of roughly 1-10 $\mu$ mol POC L ${ }^{-1}$ (e.g. Stramski et al., 2008; Neogi et al., 2012) suggests short residence times on the order of hours to days. However, TEP composition and, by extension, their bioavailability vary depending on their formation history.

\subsection{Molecular imprints of substrates and incubation time}

The central objective of this study was to explore the molecular formula composition of DOM produced by marine bacteria. The results obtained by FT-ICR MS, glucose and amino acid analyses are in agreement with studies demonstrating that microbial degradation leads to molecular transformation of DOM (e.g. Tranvik, 1993; Ogawa et al., 2001; Kujawinski et al., 2004; Gruber et al., 2006; Rossel et al., 2013). Based on the molecular formulas and their respective peak magnitudes, all treatments differed from their substrate controls and were distinguishable with respect to substrate type and incubation time (Fig. 6). In a previous study, we hypothesized that "the chemical characteristics which lead to refractory properties of DOM are similar, largely independent from the source material and mediated by microbial or photodegradation" (Koch et al., 2005). Here, we specifically wanted to verify if the material which was produced by microbes and persisted for 2 years resembled refractory organic compounds. The results demonstrated that the molecular signatures, even after 2 years of incubation, strongly differed between substrates. Therefore, our previous very general hypothesis must be rejected and refined: in fact, the molecular formulas which dominated in [Glc] treatments after 70 days were primarily compounds known for their short ocean residence times (Flerus et al., 2012; Lechtenfeld et al., 2014) and therefore do not belong to the pool of refractory compounds. However, the molecular signatures observed in the $[\mathrm{Glc}]$ treatments after 695 days became more similar to the controls (Fig. 7). This indicates at least two steps of DOM degradation: within days the very labile glucose was utilized and new DOM was generated that lasted for at least 70 days. Continued microbial activity then transformed this DOM into the refractory DOM observed after 2 years. This implies that the
DOM generated in previous, shorter-term bacterial glucose experiments might have not reached a molecular composition which resembles refractory DOM. The major chemical differences between $[\mathrm{Glc}]_{70}$ and $[\mathrm{Glc}]_{695}$ were: (i) a lower average relative contribution of hydrogen and (ii) a higher contribution of nitrogen and sulfur per molecule after 695 days.

The [exud] incubation, in contrast, resulted in a molecular composition which strongly differed from the refractory patterns. The majority of compounds which were unique or increased relative to the control were not part of typical refractory compounds, even after 2 years of incubation (Fig. 7). In contrast to the chemical changes observed in the [Glc] treatments, the [exud] treatments did not show an increase of nitrogen and sulfur between day 70 and day 695 . This might be explained by a more efficient incorporation of heteroatoms into the microbial biomass and would be consistent with higher BGE $_{\text {estim }}$ values for the exudate treatments. The DOM formed in the [exud] 695 should therefore more appropriately be termed semi-labile.

In comparison to the treatments, all control samples, except ${ }^{\text {sc }}$ [exud], showed relatively high $I_{\text {deg }}$ values indicating an advanced state of degradation. The inoculum was the exclusive source of natural organic matter in the background and ${ }^{\mathrm{sc}}[\mathrm{Glc}]$ controls, and it was derived from Antarctic surface water. The DOM from surface water in the Southern Ocean has been shown to be old (Druffel and Bauer, 2000), resulting in high $I_{\text {deg }}$ values (Lechtenfeld et al., 2014). In comparison, the [exud] incubations had much lower $I_{\text {deg }}$ values (more labile) which increased with microbial degradation. Apart from these general patterns, however, $I_{\text {deg }}$ did not show a clear trend. One possible explanation for the [Glc] treatments is that most molecular changes occurred in compounds which were in the boundary area of the patch in the van Krevelen diagram whereas the $I_{\mathrm{deg}}$ formulas are located more in the center (Fig. 6). An alternative way to assess the DOM degradation state was to compare the total relative peak magnitude of the most stable compounds (IOS, Lechtenfeld et al., 2014) to the total peak magnitude of all compounds. This comparison showed a more coherent trend in which both substrates had a smaller percentage of IOS compounds after 70 days ( $=$ more labile) and a higher contribution after 695 days (= more degraded).

Apart from variations in compounds containing carbon, hydrogen and oxygen, changes in the contribution of heteroatoms other than oxygen were also found: the contribution of molecules containing nitrogen and sulfur atoms increased in all treatments (Table 4). Accordingly, the amino acid carbon yield in the samples was increased after 41 days of incubation (Table 3). For the [Glc] and $\left[{ }^{13} \mathrm{Glc}\right]$ treatments, this was expected: the DOM was directly derived from bacteria or reworked microbial biomass which is characterized by low C / N ratios (Fukuda et al., 1998). The organic substrate in the [exud] treatments was also derived from fresh biomass (algae) and relatively low $\mathrm{C} / \mathrm{N}_{\mathrm{wa}}$ were expected. 
However, the initial $\mathrm{C} / \mathrm{N}_{\mathrm{wa}}$ ratio in the ${ }^{s c}[$ exud] 70 was comparable to the ${ }^{\mathrm{sc}}[\mathrm{Glc}]_{70}$ control, which was an additional indication that the exudates were already partly degraded before they were added to the samples. Therefore, it was reasonable that $\mathrm{C} / \mathrm{N}_{\mathrm{wa}}$ (and $\mathrm{C} / \mathrm{S}_{\mathrm{wa}}$ ) decreased similarly to the glucose incubations. Although we found, based on a principal component analysis (PCA, data not shown), that nitrogen and sulfur containing molecular formulas contributed only a little to the sample heterogeneity, their occurrence might be a good indicator for microbial alteration in future studies. The increase of the heteroatom contribution by microbial activity (as determined with FT-ICR MS) was also observed in other experiments and environments (Schmidt et al., 2009; Liao et al., 2012; Rossel et al., 2013).

Unexpectedly, the ${ }^{13} \mathrm{C}$-isotope label (D-glucose- $1-{ }^{13} \mathrm{C}$ ) was not detectable in the DOM of the $\left[{ }^{13} \mathrm{Glc}\right]$ treatments. There are several potential explanations: (i) the $\mathrm{C}_{1}$-carbon was preferentially mineralized, (ii) the labeled compounds were not extracted or not ionized and detected, (iii) the labeled compounds were below the detection limit or (iv) were preferentially embedded in the microbial biomass. A similar loss of the stable carbon isotope label was reported by Longnecker and Kujawinski (2011).

Since FT-ICR MS only yields molecular formulas and no chemical structures, it is not possible to unambiguously designate a specific compound as being refractory solely based on elemental composition and its similarity to deep ocean DOM. It should also be noted that the evaluation of sample similarity based on molecular formulas (and their respective peak magnitudes) is generally a function of molecular complexity. If the number of molecular formulas increases in sample sets, the similarity between samples must also increase, particularly if the compositional space (i.e. the possible combinations of elements in a molecule) converges the maximum of all chemically feasible combinations (Hertkorn et al., 2008). For our sample set, definite conclusions can be drawn if the elemental composition of a substance differs from the defined subset of refractory compounds (such as in the $[\mathrm{Glc}]_{70}$ treatment). In theory, the chemically relevant constitutional isomers of a molecular formula with a molecular size of $\sim 400 \mathrm{Da}$ can be immense (Hertkorn et al., 2008). However, recent studies indicate that the structural diversity in refractory material is probably limited to specific substructures and functional groups (Hertkorn et al., 2006, 2013; Witt et al., 2009).

\subsection{Implications for the marine organic carbon flux}

The molecular view derived from FT-ICR MS allowed a comparison of the organic fingerprints of DOM from the three treatments, controls and previous data on refractory marine DOM (Koch et al., 2005; Hertkorn et al., 2006). In agreement with several other studies (Nebbioso and Piccolo, 2013 and references therein), this demonstrates the potential of FT-ICR MS to unravel the transformation, source and fate of organic matter in the ocean.

The cooling of water masses in the polar oceans is the most important mechanism for the advection of DOC into the deep ocean ( $\sim 86 \mathrm{Tg} \mathrm{C}_{\mathrm{Cear}}{ }^{-1}$; Hansell et al., 2009). The formation of refractory compounds within the microbial carbon pump (Jiao et al., 2010) intensifies the process of efficient sequestration of carbon during this process. Only chemically stable compounds can be exported into the deeper ocean and stored for millennia. Generally, the experimental results supported the concept of DOM as being a consortium of organic compounds with continuous age (Flerus et al., 2012) and vast differences in ocean residence times which can be substantially longer than the bulk age of DOC (Lechtenfeld et al., 2014). If we only focus on bulk changes, the non-labile DOC removal in our study varied between 1 and $11 \mu \mathrm{mol}$ $\mathrm{CL}^{-1}$ year $^{-1}$. Compared to the lowest in situ net DOC removal rates of $0.003-0.15 \mu \mathrm{mol} \mathrm{C} \mathrm{kg}{ }^{-1}$ year $^{-1}$ in the bathypelagic zone (Hansell et al., 2009 and references therein), this was still 2-3 orders of magnitude faster. With respect to the formation of refractory DOM, our study led to ambiguous results: DOM derived from algal exudates showed molecular patterns which did not match with refractory DOM whereas the molecular signatures in the incubated [Glc] samples closely resembled refractory material after 2 years. An incubation time of 2 years is, of course, much shorter than the average residence time of refractory DOC in the deep ocean. Therefore, non-labile DOC in the environment can be further degraded and transformed by prolonged incubation, changes in the microbial community (e.g. McCarren et al., 2010; Herlemann et al., 2014) or photodegradation (Gonsior et al., 2009; Rossel et al., 2013).

If the non-labile DOC produced in the experiment (5-9\% of the substrate DOC) would be identical to refractory substances in the ocean, this would create an unreasonably high flux to the refractory DOC pool. It is therefore likely and has been shown in previous studies that mechanisms other than molecular composition contribute to the DOC preservation and degradation. A pulse of additional carbon could facilitate degradation by exceeding a chemoreceptive threshold for prokaryotes (Kattner et al., 2011). On the other hand, if the finding that a higher substrate concentration leads to a higher concentration of refractory DOM in the ocean is true, this would have a strong impact on marine carbon fluxes. The reservoir of DOC in the ocean would depend on primary production. A scenario of lower marine primary production in a more stratified future ocean would then also result in a smaller pool of carbon fixed in the refractory marine DOC.

Acknowledgements. Two anonymous reviewers and Ronald Benner are acknowledged for their helpful and constructive suggestions. Also, many thanks to Helmuth Thomas for handling the manuscript as the guest editor of this special issue. We thank Kai-Uwe Ludwichowski for amino acid and glucose analyses, Nadine Bitter, Sonja Wiegmann and Tina Brenneis for cell 
counting and Anika Schröer for assistance during the sampling. We also acknowledge Elisabeth Helmke, Oliver Lechtenfeld and Paul del Giorgio for the helpful discussion. This work was supported by the Deutsche Forschungsgemeinschaft (DFG) in the framework of the priority program Antarctic Research with comparative investigations in Arctic ice areas (grant DFG KO 2164/3-1).

Edited by: H. Thomas

\section{References}

Alderkamp, A. C., Buma, A. G. J., and van Rijssel, M.: The carbohydrates of Phaeocystis and their degradation in the microbial food web, Biogeochemistry, 83, 99-118, 2007.

Alldredge, A. L., Passow, U., and Logan, B. E.: The abundance and significance of a class of large, transparent organic particles in the ocean, Deep-Sea Res. I, 40, 1131-1140, 1993.

Arnosti, C.: Speed bumps and barricades in the carbon cycle: substrate structural effects on carbon cycling, Mar. Chem., 92, 263273, 2004.

Arrigo, K. R.: Carbon cycle - Marine manipulations, Nature, 450, 491-492, 2007.

Azam, F. and Long, R. A.: Oceanography - Sea snow microcosms, Nature, 414, 495-498, 2001.

Bauer, J. E., Williams, P. M., and Druffel, E. R. M.: ${ }^{14} \mathrm{C}$ activity of dissolved organic carbon fractions in the north-central Pacific and Sargasso Sea, Nature, 357, 667-670, 1992.

Benner, R. and Herndl, G. J.: Bacterially derived dissolved organic matter in the microbial carbon pump, in: Microbial carbon pump in the Ocean, edited by: Jiao, N., Azam, F., and Sanders, S., Science/AAAS, Washington, DC, 46-48, 2011.

Bianchi, T. S.: The role of terrestrially derived organic carbon in the coastal ocean: A changing paradigm and the priming effect, Proc. Natl. Acad. Sci. USA, 108, 19473-19481, 2011.

Bjornsen, P. K. and Kuparinen, J.: Determination of bacterioplankton biomass, net production and growth efficiency in the Southern Ocean, Mar. Ecol. Prog. Ser., 71, 185-194, 1991.

Bray, J. R. and Curtis, J. T.: An ordination of the upland forest communities of southern Wisconsin, Ecol. Monogr., 27, 273-279, 1957.

Brophy, J. E. and Carlson, D. J.: Production of biologically refractory dissolved organic carbon by natural seawater microbial populations, Deep-Sea Res. Pt. I, 36, 497-507, 1989.

Carlson, C. A., Ducklow, H. W., and Michaels, A. F.: Annual flux of dissolved organic carbon from the euphotic zone in the northwestern Sargasso Sea, Nature, 371, 405-408, 1994.

Carlson, C. A., Hansell, D. A., Nelson, N. B., Siegel, D. A., Smethie, W. M., Khatiwala, S., Meyers, M. M., and Halewood, E.: Dissolved organic carbon export and subsequent remineralization in the mesopelagic and bathypelagic realms of the North Atlantic basin, Deep-Sea Res. Pt I, 57, 1433-1445, 2010.

Cavalli, F., Facchini, M. C., Decesari, S., Mircea, M., Emblico, L., Fuzzi, S., Ceburnis, D., Yoon, Y. J., O’Dowd, C. D., Putaud, J. P., and Dell'Acqua, A.: Advances in characterization of sizeresolved organic matter in marine aerosol over the North Atlantic, J. Geophys. Res.-Atmos., 109, 14 pp., 2004. del Giorgio, P. A. and Cole, J. J.: Bacterial growth efficiency in natural aquatic systems, Ann. Rev. Ecol. System., 29, 503-541, 1998.

Denman, K. L., Brasseur, G., Chidthaisong, A., Ciais, P., Cox, P. M., Dickinson, R. E., Hauglustaine, D., Heinze, C., Holland, E., Jacob, D., Lohmann, U., Ramachandran, S., da Silva Dias, P. L., Wofsy, S. C., and Zhang, X.: Couplings Between Changes in the Climate System and Biogeochemistry, in: Climate Change 2007: The Physical Science Basis. Contribution of Working Group I to the Fourth Assessment Report of the Intergovernmental Panel on Climate Change, edited by: Solomon, S., Qin, D., Manning, M., Chen, Z., Marquis, M., Averyt, K. B., Tignor, M., and Miller, H. L., Cambridge University Press, Cambridge, United Kingdom and New York, NY, USA, 940 pp., 2007.

Dittmar, T., Koch, B., Hertkorn, N., and Kattner, G.: A simple and efficient method for the solid-phase extraction of dissolved organic matter (SPE-DOM) from seawater, Limnol. Oceanogr.Meth., 6, 230-235, 2008.

Druffel, E. R. M. and Bauer, J. E.: Radiocarbon distributions in Southern Ocean dissolved and particulate organic matter, Geophys. Res. Lett., 27, 1495-1498, 2000.

Engbrodt, R. and Kattner, G.: On the biogeochemistry of dissolved carbohydrates in the Greenland Sea (Arctic), Organ. Geochem., 36, 937-948, 2005.

Fitznar, H. P., Lobbes, J. M., and Kattner, G.: Determination of enantiomeric amino acids with high-performance liquid chromatography and pre-column derivatisation with $o$ phthaldialdehyde and $\mathrm{N}$-isobutyrylcysteine in seawater and fossil samples (mollusks), J. Chromatogr. A, 832, 123-132, 1999.

Flerus, R., Koch, B. P., Schmitt-Kopplin, P., Witt, M., and Kattner, G.: Molecular level investigation of reactions between dissolved organic matter and extraction solvents using FT-ICR MS, Mar. Chem., 124, 100-107, 2011.

Flerus, R., Lechtenfeld, O. J., Koch, B. P., McCallister, S. L., Schmitt-Kopplin, P., Benner, R., Kaiser, K., and Kattner, G.: A molecular perspective on the ageing of marine dissolved organic matter, Biogeosciences, 9, 1935-1955, doi:10.5194/bg-9-19352012, 2012.

Fukuda, R., Ogawa, H., Nagata, T., and Koike, I.: Direct determination of carbon and nitrogen contents of natural bacterial assemblages in marine environments, Appl. Environ. Microbiol., 64, 3352-3358, 1998.

Gardes, A., Iversen, M. H., Grossart, H. P., Passow, U., and Ullrich, M. S.: Diatom-associated bacteria are required for aggregation of Thalassiosira weissflogii, Isme Journal, 5, 436-445, 2011.

Gonsior, M., Peake, B. M., Cooper, W. T., Podgorski, D., D'Andrilli, J., and Cooper, W. J.: Photochemically Induced Changes in Dissolved Organic Matter Identified by Ultrahigh Resolution Fourier Transform Ion Cyclotron Resonance Mass Spectrometry, Environ. Sci. Technol., 43, 698-703, 2009.

Gonsior, M., Zwartjes, M., Cooper, W. J., Song, W. H., Ishida, K. P., Tseng, L. Y., Jeung, M. K., Rosso, D., Hertkorn, N., and SchmittKopplin, P.: Molecular characterization of effluent organic matter identified by ultrahigh resolution mass spectrometry, Water Res., 45, 2943-2953, 2011.

Grasshoff, K., Kremling, K., and Ehrhardt, M.: Methods of Seawater Analysis, 3rd edition, Wiley, New York, 1999.

Gruber, D. F., Simjouw, J. P., Seitzinger, S. P., and Taghon, G. L.: Dynamics and characterization of refractory dissolved organic 
matter produced by a pure bacterial culture in an experimental predator-prey system, Appl. Environ. Microbiol., 72, 4184-4191, 2006.

Guillard, R. R. L.: Culture of phytoplankton for feeding marine invertebrates, in: Culture of marine invertebrate animals, edited by: Smith, W. L. and Chanley, M. H., Plenum Press, New York, 2660, 1975.

Guillard, R. R. L. and Ryther, J. H.: Studies of marine planktonic diatoms, I. Cyclotella nana Hustedt and Detonula confervacea Cleve, Canad. J. Microbiol., 8, 229-239, 1962.

Hansell, D. A.: Recalcitrant dissolved organic carbon fractions, Ann. Rev. Mar. Sci., 5, 421-445, 2013.

Hansell, D. A., Carlson, C. A., Repeta, D. J., and Schlitzer, R.: Dissolved organic matter in the ocean: a controversy stimulates new insights, Oceanography, 22, 202-211, 2009.

Herlemann, D. P. R., Manecki, M., Meeske, C., Pollehne, F., Labrenz, M., Schulz-Bull, D., Dittmar, T., and Jurgens, K.: Uncoupling of bacterial and terrigenous dissolved organic matter dynamics in decomposition experiments, Plos One, 9, 12 pp., 2014

Hertkorn, N., Benner, R., Frommberger, M., Schmitt-Kopplin, P., Witt, M., Kaiser, K., Kettrup, A., and Hedges, J. I.: Characterization of a major refractory component of marine dissolved organic matter, Geochim. Cosmochim. Ac., 70, 2990-3010, 2006.

Hertkorn, N., Frommberger, M., Witt, M., Koch, B. P., SchmittKopplin, P., and Perdue, E. M.: Natural organic matter and the event horizon of mass spectrometry, Anal. Chem., 80, 89088919, 2008.

Hertkorn, N., Harir, M., Koch, B. P., Michalke, B., and SchmittKopplin, P.: High-field NMR spectroscopy and FTICR mass spectrometry: powerful discovery tools for the molecular level characterization of marine dissolved organic matter, Biogeosciences, 10, 1583-1624, doi:10.5194/bg-10-1583-2013, 2013.

Horvath, R. S.: Microbial co-metabolism and degradation of organic compounds in nature, Bacteriol. Rev., 36, 146-155, 1972.

Hughey, C. A., Galasso, S. A., and Zumberge, J. E.: Detailed compositional comparison of acidic NSO compounds in biodegraded reservoir and surface crude oils by negative ion electrospray Fourier transform ion cyclotron resonance mass spectrometry, Fuel, 86, 758-768, 2007.

Jiao, N., Herndl, G. J., Hansell, D. A., Benner, R., Kattner, G., Wilhelm, S. W., Kirchman, D. L., Weinbauer, M. G., Luo, T. W., Chen, F., and Azam, F.: Microbial production of recalcitrant dissolved organic matter: long-term carbon storage in the global ocean, Nat. Rev. Microbiol., 8, 593-599, 2010.

Johnson, D. C. and LaCourse, W. R.: Liquid chromatography with pulsed electrochemical detection at gold and platinum electrodes, Anal. Chem., 62, 589A-597A, 1990.

Kattner, G. and Becker, H.: Nutrients and organic nitrogenous compounds in the marginal ice zone of the Fram Strait, J. Mar. Syst., 2, 385-394, 1991.

Kattner, G., Simon, M., and Koch, B. P.: Molecular characterization of dissolved organic matter and constraints for prokaryotic utilization, in: Microbial carbon pump in the ocean, edited by: Jiao, N., Azam, F., and Sanders, S., Science/AAAS, Washington, DC, 60-61, 2011.

Kawasaki, N. and Benner, R.: Bacterial release of dissolved organic matter during cell growth and decline: Molecular origin and composition, Limnol. Oceanogr., 51, 2170-2180, 2006.
Kemp, P. F., Sherr, B. F., Sherr, E. B., and Cole, J. J.: Handbook of methods in aquatic microbial ecology, Lewis Pub., 1993.

Kim, S., Kramer, R. W., and Hatcher, P. G.: Graphical method for analysis of ultrahigh-resolution broadband mass spectra of natural organic matter, the Van Krevelen Diagram, Anal. Chem., 75, 5336-5344, 2003.

Koch, B. P., Witt, M., Engbrodt, R., Dittmar, T., and Kattner, G.: Molecular formulae of marine and terrigenous dissolved organic matter detected by electrospray ionisation Fourier transform ion cyclotron resonance mass spectrometry, Geochim. Cosmochim. Ac., 69, 3299-3308, 2005.

Koch, B. P., Dittmar, T., Witt, M., and Kattner, G.: Fundamentals of molecular formula assignment to ultrahigh resolution mass data of natural organic matter, Anal. Chem., 79, 1758-1763, 2007.

Koch, B. P., Ludwichowski, K.-U., Kattner, G., Dittmar, T., and Witt, M.: Advanced characterization of marine dissolved organic matter by combining reversed-phase liquid chromatography and FT-ICR-MS, Mar. Chem., 111, 233-241, 2008.

Kujawinski, E. B.: Electrospray ionization Fourier transform ion cyclotron resonance mass spectrometry (ESI FT-ICR MS): characterization of complex environmental mixtures, Environ. Foren., 3, 207-216, 2002.

Kujawinski, E. B., Del Vecchio, R., Blough, N. V., Klein, G. C., and Marshall, A. G.: Probing molecular-level transformations of dissolved organic matter: insights on photochemical degradation and protozoan modification of DOM from electrospray ionization Fourier transform ion cyclotron resonance mass spectrometry, Mar. Chem., 92, 23-37, 2004.

Lechtenfeld, O. J., Koch, B. P., Gašparović, B., Frka, S., Witt, M., and Kattner, G.: The influence of salinity on the molecular and optical properties of surface microlayers in a karstic estuary, Mar. Chem., 150, 25-38, 2013.

Lechtenfeld, O. J., Kattner, G., Flerus, R., McCallister, S. L., Schmitt-Kopplin, P., and Koch, B. P.: Molecular transformation and degradation of refractory dissolved organic matter in the Atlantic and Southern Ocean, Geochim. Cosmochim. Ac., 126, 321-337, 2014.

Leppard, G. G.: The characterization of algal and microbial mucilages and their aggregates in aquatic ecosystems, Sci. Total Environ., 165, 103-131, 1995.

Liao, Y. H., Shi, Q., Hsu, C. S., Pan, Y. H., and Zhang, Y. H.: Distribution of acids and nitrogen-containing compounds in biodegraded oils of the Liaohe Basin by negative ion ESI FT-ICR MS, Organ. Geochem., 47, 51-65, 2012.

Logan, B. E., Passow, U., Alldredge, A. L., Grossart, H. P., and Simon, M.: Rapid formation and sedimentation of large aggregates is predictable from coagulation rates (half-lives) of transparent exopolymer particles (TEP), Deep-Sea Res. Pt. I, 42, 203-214, 1995.

Loh, A. N., Bauer, J. E., and Druffel, E. R. M.: Variable ageing and storage of dissolved organic components in the open ocean, Nature, 430, 877-881, 2004.

Lonborg, C., Alvarez-Salgado, X. A., Martinez-Garcia, S., Miller, A. E. J., and Teira, E.: Stoichiometry of dissolved organic matter and the kinetics of its microbial degradation in a coastal upwelling system, Aq. Microb. Ecol., 58, 117-126, 2010.

Longnecker, K. and Kujawinski, E. B.: Composition of dissolved organic matter in groundwater, Geochim. Cosmochim. Ac., 75, 2752-2761, 2011 . 
McCarren, J., Becker, J. W., Repeta, D. J., Shi, Y. M., Young, C. R., Malmstrom, R. R., Chisholm, S. W., and DeLong, E. F.: Microbial community transcriptomes reveal microbes and metabolic pathways associated with dissolved organic matter turnover in the sea, Proc. Natl. Acad. Sci. USA, 107, 16420-16427, 2010.

Mopper, K., Schultz, C. A., Chevolot, L., Germain, C., Revuelta, R., and Dawson, R.: Determination of sugars in unconcentrated seawater and other natural waters by liquid chromatography and pulsed amperometric detection, Environ. Sci. Technol., 26, 133138, 1992.

Mopper, K., Zhou, J., Ramana, K. S., Passow, U., Dam, H. G., and Drapeau, D. T.: The role of surface-active carbohydrates in the flocculation of a diatom bloom in a mesocosm, Deep-Sea Res. II, 42, 47-73, 1995.

Myklestad, S. M.: release of extracellular products by phytoplankton with special emphasis on polysaccharides, Sci. Total Environ., 165, 155-164, 1995.

Nebbioso, A. and Piccolo, A.: Molecular characterization of dissolved organic matter (DOM): a critical review, Anal. Bioanal. Chem., 405, 109-124, 2013.

Neogi, S. B., Islam, M. S., Nair, G. B., Yamasaki, S., and Lara, R. J.: Occurrence and distribution of plankton-associated and freeliving toxigenic Vibrio cholerae in a tropical estuary of a cholera endemic zone, Wetlands Ecol. Manag., 20, 271-285, 2012.

Noble, R. T. and Fuhrman, J. A.: Use of SYBR Green I for rapid epifluorescence counts of marine viruses and bacteria, Aq. Microb. Ecol., 14, 113-118, 1998.

Ogawa, H., Amagai, Y., Koike, I., Kaiser, K., and Benner, R.: Production of refractory dissolved organic matter by bacteria, Science, 292, 917-920, 2001.

Ortega-Retuerta, E., Reche, I., Pulido-Villena, E., Agusti, S., and Duarte, C. M.: Uncoupled distributions of transparent exopolymer particles (TEP) and dissolved carbohydrates in the Southern Ocean, Mar. Chem., 115, 59-65, 2009.

Passow, U.: Formation of transparent exopolymer particles, TEP, from dissolved precursor material, Mar. Ecol. Prog. Ser., 192, 1$11,2000$.

Passow, U.: Transparent exopolymer particles (TEP) in aquatic environments, Prog. Oceanogr., 55, 287-333, 2002a.

Passow, U.: Production of transparent exopolymer particles (TEP) by phyto- and bacterioplankton, Mar. Ecol. Prog. Ser., 236, 1-12, 2002b.

Passow, U. and Alldredge, A. L.: Distribution, size and bacterial colonization of transparent exopolymer particles (TEP) in the ocean, Mar. Ecol. Prog. Ser., 113, 185-198, 1994.

Passow, U. and Alldredge, A. L.: A dye-binding assay for the spectrophotometric measurement of transparent exopolymer particles (TEP), Limnol. Oceanogr., 40, 1326-1335, 1995.

Passow, U., Alldredge, A. L., and Logan, B. E.: The role of particulate carbohydrate exudates in the flocculation of diatom blooms, Deep-Sea Res., 41, 335-357, 1994.

Porter, K. G. and Feig, Y. S.: The use of DAPI for identifying and counting aquatic microflora, Limnol. Oceanogr., 25, 943-948, 1980.

Rodgers, R. P., Blumer, E. N., Emmett, M. R., and Marshall, A. G.: Efficacy of bacterial bioremediation: Demonstration of complete incorporation of hydrocarbons into membrane phospholipids from Rhodococcus hydrocarbon degrading bacteria by electro- spray ionization Fourier transform ion cyclotron resonance mass spectrometry, Environ. Sci. Technol., 34, 535-540, 2000.

Rossel, P. E., Vahatalo, A. V., Witt, M., and Dittmar, T.: Molecular composition of dissolved organic matter from a wetland plant (Juncus effusus) after photochemical and microbial decomposition (1.25 year): Common features with deep sea dissolved organic matter, Organic Geochem., 60, 62-71, 2013.

Schmidt, F., Elvert, M., Koch, B. P., Witt, M., and Hinrichs, K.-U.: Molecular characterization of dissolved organic matter in pore water of continental shelf sediments, Geochim. Cosmochim. Ac., 73, 3337-3358, 2009.

Schmidt, F., Koch, B. P., Elvert, M., Schmidt, G., Witt, M., and Hinrichs, K. U.: Diagenetic Transformation of Dissolved Organic Nitrogen Compounds under Contrasting Sedimentary Redox Conditions in the Black Sea, Environ. Sci. Technol., 45, 5223-5229, 2011.

Skoog, A., Biddanda, B., and Benner, R.: Bacterial utilization of dissolved glucose in the upper water column of the Gulf of Mexico, Limnol. Oceanogr., 44, 1625-1633, 1999.

Smith, D. C., Simon, M., Alldredge, A. L., and Azam, F.: Intense Hydrolytic Enzyme-Activity on Marine Aggregates and Implications for Rapid Particle Dissolution, Nature, 359, 139-142, 1992.

Stoderegger, K. E. and Herndl, G. J.: Production of exopolymer particles by marine bacterioplankton under contrasting turbulence conditions, Mar. Ecol.-Prog. Ser., 189, 9-16, 1999.

Stramski, D., Reynolds, R. A., Babin, M., Kaczmarek, S., Lewis, M. R., Röttgers, R., Sciandra, A., Stramska, M., Twardowski, M. S., Franz, B. A., and Claustre, H.: Relationships between the surface concentration of particulate organic carbon and optical properties in the eastern South Pacific and eastern Atlantic Oceans, Biogeosciences, 5, 171-201, doi:10.5194/bg-5-171-2008, 2008.

Sugimoto, K., Fukuda, H., Baki, M. A., and Koike, I.: Bacterial contributions to formation of transparent exopolymer particles (TEP) and seasonal trends in coastal waters of Sagami Bay, Japan, Aq. Microb. Ecol., 46, 31-41, 2007.

Tranvik, L. J.: Microbial transformation of labile dissolved organic matter into humic-like matter in seawater, Fems Microbiol. Ecol., 12, 177-183, 1993.

Vallino, J. J., Hopkinson, C. S., and Hobbie, J. E.: Modeling bacterial utilization of dissolved organic matter: Optimization replaces Monod growth kinetics, Limnol. Oceanogr., 41, 15911609, 1996.

van Krevelen, D. W.: Graphical-statistical method for the study of structure and reaction processes of coal, Fuel, 29, 269-284, 1950.

Verdugo, P., Alldredge, A. L., Azam, F., Kirchman, D. L., Passow, U., and Santschi, P. H.: The oceanic gel phase: a bridge in the DOM-POM continuum, Mar. Chem., 92, 67-95, 2004.

Witt, M., Fuchser, J., and Koch, B. P.: Fragmentation studies of Fulvic Acids using Collision Induced Dissociation Fourier Transform Ion Cyclotron Resonance Mass Spectrometry, Anal. Chem., 81, 2688-2694, 2009.

Zhou, J., Mopper, K., and Passow, U.: The role of surface-active carbohydrates in the formation of transparent exopolymer particles by bubble adsorption of seawater, Limnol. Oceanogr., 43 , 1860-1871, 1998. 